\title{
Reconciliation and Nonrepetition:
}

\section{A New Paradigm for African- American Reparations}

\begin{abstract}
The contemporary paradigm for African-American reparations fundamentally fails to address what should be its most vital component. Of the three essential elements of a successful reparations campaign-apology, award, and nonrepetition through reconciliation-the most vital is nonrepetition. In past "successful" reparations campaigns, the offending parties have issued apologies and awards, but have neither challenged nor dismantled the attitudes or infrastructures from which wrongful acts emerged, leaving open the likelihood of wrongful acts occurring again. Any campaign that neglects the nonrepetition element runs the risk of strengthening the status quo. In this Article, Professor Burkett argues that in order for a reparations campaign to be a true success for African-Americans, it must include a nonrepetition element. To do so, the reparations movement must embrace a reconciliation model that is forward looking, and concerned with the methods of deterring future bad acts for ultimate, complete, and successful repair. In the current discourse on African-

* Associate Professor of Law, University of Colorado Law School. Williams College, B.A.; University of California, Berkeley (Boalt Hall School of Law), J.D. The author would like to thank Emily Calhoun, Jane Cross, Nestor Davidson, Angela-Harris, Clare Huntington, Sarah Krakoff, Deborah Post, Alfreda Robinson, Pierre Schlag, Joshua Stanbro, and Ahmed White for their invaluable feedback. The author would also like to thank Jennifer Dilalla for her unparalleled research assistance.
\end{abstract}


American reparations, Professor Burkett argues, nonrepetition through reconciliation is woefully underemphasized. The incorporation of the nonrepetition element is particularly important in the American context. From the nation's earliest days, the American political and economic landscape has evolved in a particularly pernicious manner, creating and entrenching a racial and economic hierarchy that persistently subjugates African-Americans and other of-color and lowincome communities. Professor Burkett argues that in this context, a multiracial, multiethnic, and cross-class reconciliation model is vital to the success of the African-American campaign. This broad-based approach, the author maintains, is the only way to ensure nonrepetition.

The contemporary paradigm for African-American reparations for slavery and its legacy fundamentally fails to address what should be its most vital component. Any successful reparations must contain three critical elements. The first element on the path to repair is an apology. The second element is a monetary or other award that gives actual or symbolic weight to that apology. However, the true weight of an apology and redress is felt in the commitment by the perpetrator not to repeat the act. It follows the simple lesson taught to children"sorry" is limited in its effect. One must promise to try, vigilantly, not to commit the act again. An apology and remuneration alone are, therefore, insufficient. The third and most vital element of a reparations campaign is the guarantee of nonrepetition.

The current movement for reparations, however, fails to demand and secure this most important element of repair. The movement for African-American reparations thus seeks remedies that fall short of forcing structural change that will produce true social transformation. It makes an impossible request in a hostile arena, and at the same time does little to dissipate the very cloud of hostility that makes the social, legal, and political space so inhospitable. In short, the current movement for African-American reparations simply asks for too little.

In the current discourse on African-American reparations for slavery and its legacy, the focus on monetary reparations for 
injuries suffered by African-Americans is misguided. ${ }^{1}$ The emphasis on reparations with respect to actual monetary losses, as well as psychological and community damages, pulls energy away from efforts to address larger systemic changes that need to occur in a race-riddled society. Furthermore, in accepting traditional forms of reparations, African-Americans aid in perpetuating the very system that allows for their persistent subjugation and the subjugation of other of-color communities.

Although a number of proposed remedies focus on building programs, arguments demanding monetary liability are often said and heard most loudly, and, to be sure, money transfers are integral to erecting necessary programs. This focus on money transfers or payments is based largely on the belief that American society is so riddled with racism and its permanency that monetary awards are the only true means of change for which African-Americans can hope. Closing the economic gap between black and white Americans is a vital component in remedying the plight of African-Americans. It is impossible, however, for money allotments to have substantive and lasting meaning beyond temporary currency in the marketplace.

Rather than risking reinforcement of the status quo with respect to widening class divides and the formidable power of monied groups, challenging the economic structure and the manner in which economic and political power exists in America is the conceptual core around which reparationists must frame their argument and the ensuing debate. Thus, I contend that the reparations movement should focus on the larger goal of transformation by meeting the demands of the nonrepetition prong. I fully acknowledge that this is a far-reaching task, but it is necessary to repair the damage done. Realization of any number of alternative futures that may pull American society out of its current loop requires an adequate response to centuries of legalized subjugation followed by extralegal oppression, individual and systemic. This may well demand a fundamental shift in America's economic, political, and social structures. While crafting and implementing differing structures

1 To be sure, some scholars and activists seek the precursor to monetary awards, an apology, but even this broader view of reparations fails to appreciate the critical need for nonrepetition. 
may be a daunting task, African-Americans must begin the long march toward realizing these alternative futures.

The reparations debate itself provides an incomparably valuable opportunity for all Americans to come to terms with the truth of their history. It is an historic moment that offers a chance to rediscover, or perhaps introduce, compassion in and for all Americans. ${ }^{2}$ This debate provides unparalleled potential to explore the racial and economic hierarchies that have defined American social construction for over three centuries. Yet the dangers of pursuing reparations without faithfully pursuing the third element of repair are great, as African-Americans risk perpetuating American social hierarchy by reshuffling the players without dismantling the game.

To be clear, I am not the familiar dissenter in reparations debates. ${ }^{3}$ I do not believe that reparations claims are without basis. In fact, in light of the centuries of indignities suffered by African-Americans, reparations are absolutely warranted. ${ }^{4}$ I

2 Kevin Merida offers poignantly: "Few questions challenge us to consider 380 years of history all at once, to tunnel inside our souls to discover what we truly believe about race and equality and the value of human suffering." Kevin Merida, Did Freedom Alone Pay a Nation's Debt?, WASH. POST, Nov. 23, 1999, at C1.

3 Many African-American dissenters believe that it is a hopeless and impractical crusade. Stanford African-American history professor Clay Carson argues that reparations is not only unrealistic, but it is also "'appealingly simplistic.'" Jenifer Warren, Demanding Repayment for Slavery, L.A. TIMES, July 6, 1994, at A1. Others, like Walter Williams, object on "moral grounds." Id. Williams, a conservative black columnist and professor of economics at George Mason University, argues that it is "'perverse ... to suggest that some poor white kid who's the son of a coal miner in West Virginia owes me-someone in the top $1 \%$ or $2 \%$ of income earners in the U.S.-money." Id. Another conservative, AfricanAmerican commentator Armstrong Williams, stated: "It would literally pay to be black .... Everybody and their momma would claim they were black." Merida, supra note 2.

4 To say reparations are warranted is not, of course, to say a campaign will succeed. Many commentators have speculated on the possible negative outcome of a reparations campaign. Derrick Bell, civil rights activist and Harvard law professor, has remarked that " “ $[r]$ acial reparations ... are more a vision than a legal possibility." JOHN TORPEY, MAKING WHOLE WHAT HAS BEEN SMASHED: ON REPARATIONS POLITICS 115 (2006). Adolph Reed, a progressive and New School University political scientist, has dismissed the pursuit of reparations as a "'political dead end"" and "'so obviously a nonstarter in American politics." Id. at 120. And Time Magazine columnist Jack E. White wrote in his column that "the fight for slave reparations is a morally just but totally hopeless cause."' Id. See also Saul Levmore, Privatizing Reparations, 84 B.U. L. REV. 1291, 1292 (2004) (describing African-American reparations as "an impossibly academic topic" and "[a]s a purely positive matter... unlikely to materialize."). 
instead seek something qualitatively different from what many of the most enthusiastic reparations proponents advocate. I am seeking reconciliation-and a concomitant guarantee of nonrepetition-through profound social change.

In Part I, I briefly survey the history and contemporary claims of the African-American reparations movement. I then evaluate the viability of the current reparations paradigm, foregrounding the peculiarly individualistic and historically prejudicial American context within which those claims are brought. I seek to highlight the characteristics of the American political economy on which current claims rely, but which are themselves vital targets for effective reparations.

In Part II, I argue for a redefining of the African-American reparations movement, focusing on a restructuring that can meet the mandates of nonrepetition. I look to the Japanese-American reparations campaign and argue that the Japanese-American experience provides not a model for emulation, but a crucial cautionary tale. The failure to address nonrepetition in obtaining reparations reinforces the political, social, and economic status quo.

In Part III, I expand upon the potential dangers of reparations pursued within the current paradigm and argue that the most important failing of the contemporary reparations struggle is its limited scope. A limit in scope indicates dwindled optimism about fashioning an alternative future. This diminished optimism has serious consequences: as John Torpey poignantly declares, "[w]hen the future collapses, the past rushes in." I conclude by arguing for the infusion of a grander vision of social justice in African-American claims, and by advocating for an alternative reparations campaign focusing on structural change.

My purpose here is not to prescribe a particular roadmap for meeting the mandates of nonrepetition, although I do offer some suggestions. Instead, my aim is to initiate a discussion among African-American reparationists that will shift the focus to the vital need for a movement centered on nonrepetition. Indeed, a fundamental ideological shift in the movement is essential to repair the very brokenness inextricably interwoven in the American cultural machine-a brokenness that produces and

5 TORPEY, supra note 4, at 24 . 
reproduces the economic and racial subjugation on which this country has historically depended for its prosperity.

\section{THE AFRICAN-AMERICAN CLAIMS}

\section{A. Defining Our Terms}

As an initial matter, it is important to define the term that, ultimately, defines the movement. "Reparations" has been used somewhat carelessly in the contemporary debate on AfricanAmerican reparations, such that the term has no easily identifiable conceptual boundary or historical relevance. ${ }^{6}$ However, in order for the African-American reparations movement to have force in the public discourse, it is important for it to have an internal consistency. In other words, the popular understanding of "reparations" must be consistent with the goals and motivations of the African-American reparations movement for the movement to make sense to itself and the larger society.

Historically, "reparations" described postwar payouts by a defeated entity to the victor." Synonymous with "indemnities," reparations were payments that the losers of a war were responsible for making to the winner for the damage caused by the conflict. ${ }^{8}$ After World War II the term took on a slightly different meaning. ${ }^{9}$ Most notably, the flow of cash would now move from those in the dominant position, or those culpable in the commission of the offending event, to the victims of the offense. ${ }^{10}$ The core principles of compensatory justice, which affirm that injuries must be compensated and wrongdoers should

\footnotetext{
${ }^{6}$ It is true that the nebulous nature of this term is inherent. According to John Torpey, "reparations is in part a terminological matter, and hence one of perception-reparations may be whatever transfer one chooses to call reparations." Id. at 146.

7 See id. at $42-43$.

8 See id. at 43.

9 See id.

10 One commentator has applied a more nuanced definition, stating that “'reparations' [means] compensation, often monetary, paid by a sovereign long after the underlying injury was suffered and the legal regime has been changed." Lee A. Harris, "Reparations" as a Dirty Word: The Norm Against Slavery Reparations, 33 U. MEM. L. REV. 409, 410 n.7 (2003).
} 
pay victims for losses, have persisted in reparations since its inception. Today, however, nations often use land and money as a way to atone for sins committed against their own citizens or their neighbors. ${ }^{11}$ This is the key difference between late twentieth-century notions of reparations and earlier popular understandings. While the beneficiaries of such payouts have shifted from victor to victim, cash payout is still the pivotal remedy around which all claims turn.

Compensation also plays a vital role in the contemporary African-American reparations discourse. In fact, for many, it gives actual meaning to both the request for and the receipt of reparations. A request for compensation is evidence that a community had something that was lost and that a distinct perpetrator was responsible for that loss. ${ }^{12}$ Sketched in economic terms, the perpetrator, the victim, and those observing recognize the economic implications of that loss, ${ }^{13}$ and the receipt of monetary reparations is then the logical product of the request. In the case of African-Americans, almost all demands for monetary remedies are based on achieving parity, rather than economic dominance. They are an attempt to level the playing field and fill the lacuna that currently exists between the white and black economic worlds.

In legal academic discourse, reparations is not necessarily distinct from other more commonplace legal remedies. In fact, according to some commentators, reparations has no clear conceptual boundaries that demarcate it from other legal remedies based on compensatory and corrective justice principles, nor from other large-scale governmental transfer

11 See Lori S. Robinson, Righting a Wrong Among Black Americans: The Debate Is Escalating over Whether an Apology for Slavery Is Enough, SEATTLE POSTINTELLIGENCER, June 29, 1997, at E1. Robinson states:

Nations are paying damages for injuries and wrongdoing with land and money.

In international law, making amends or giving satisfaction for a wrong or injury-as reparations is defined-is standard practice. The United Nations negotiates it. The International Court of Justice orders it. Some nations even give it without prodding from foreign governments or institutions.

Id.

12 See W. Burlette Carter, True Reparations, 68 GEO. WASH. L. REV. 1021, 1027 (2000).

13 See id. 
programs. ${ }^{14}$ Here, one significant marker of reparations "schemes" is their backward-looking character. ${ }^{15}$ In other words, reparations schemes are justified on the basis of "remediation of, or compensation for, past injustices." 16 This justification is in contrast to more forward-looking objectives, which include promoting distributive justice and, most importantly, deterring future wrongdoing.

\section{B. A Brief History of the African-American Reparations Struggle}

A number of individuals ${ }^{18}$ and organizations have participated in the reparations movement. ${ }^{19}$ These individuals and

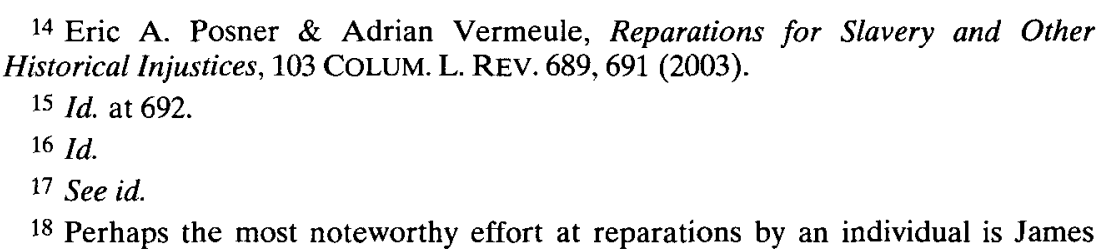
Foreman's 1969 demand for reparations. Foreman, a former leader of the Student Nonviolent Coordinating Committee ("SNCC"), prepared The Black Manifesto, which he read at Riverside Church in New York City after interrupting its Sunday morning service. Irma Jacqueline Ozer, Reparations for African Americans, 41 How. L.J. 479, 494 (1998). Foreman's manifesto demanded that churches and synagogues pay $\$ 500$ million " as a beginning of the reparations due us as people who have been exploited and degraded, brutalized, killed, and persecuted."' Id. Perhaps unsurprisingly, the media response to the Manifesto was "cold and dismissive." Id. For a reprint of Foreman's The Black Manifesto, see BORIS I. BITTKER, THE CASE FOR BLACK REPARATIONS 159 app. A (1973). For detailed descriptions of The Black Manifesto, see generally Art Alcausin Hall, There Is a Lot to Be Repaired Before We Get to Reparations: A Critique of the Underlying Issues of Race that Impact the Fate of African American Reparations, 2 SCHOLAR 1, 18-19 (2000); Eric K. Yamamoto, Racial Reparations: Japanese American Redress and African American Claims, 40 B.C. L. REV. 477, 495 (1998) [hereinafter Yamamoto, Racial Reparations].

19 Organizations include the National Conference of Black Lawyers, whose director characterized the reparations movement as an effort "to repair a people for significant harm that was done to them and particularly done to them by a government." Hall, supra note 18, at 11-12 (citation omitted). Jesse Jackson, Coretta Scott King, the NAACP, and the Southern Christian Leadership Conference (SCLC) have also expressed support. Warren, supra note 3. Several cities, including Detroit, Cleveland, and the District of Columbia have passed resolutions endorsing the basic principle of reparations. Id. Grassroots activist organizations nationwide include the following: African American Reparations Committee, Inc., Boston, Massachusetts; Afrikan Americans for ReparationsReparations Now Committee, Washington, D.C.; African National Reparations Organization, Baltimore, MD; Black Reparation Commission, Rockville, MD; Self Determination Committee, Los Angeles, CA; and Ida Hakim's Caucasians United for Reparations and Emancipation. Vincene Verdun, If the Shoe Fits, Wear It: An 
organizations have been involved in four major waves of reparations activism, each wave marked by major instigating events. ${ }^{20}$

The first wave occurred in the $1860 \mathrm{~s}^{21}$ There were numerous efforts from the legislative and executive branches to provide economic support to the newly emancipated. The most readily identifiable, due in large part to its ubiquity in black popular culture, ${ }^{22}$ is General William Sherman's Special Field Order

Analysis of Reparations to African Americans, 67 TUL. L. REV. 597, 606 n.27 (1993); Crystal L. Keels, Still No 40 Acres, Still No Mule, BlaCk IssuES IN Higher EduC., Aug. 11, 2005, at 20.

The National Coalition of Blacks for Reparations ("N'COBRA"), founded in 1987, has, arguably, led the greatest grassroots effort. N'COBRA grounds its legal claim in the Thirteenth and Fourteenth Amendments and civil rights statutes. Additionally, it forwards international law principles and standards of equality and self-determination. For further discussion of N'COBRA, see Yamamoto, Racial Reparations, supra note 18 , at 502-03, 510-11, 515 .

20 Some identify more than four waves of reparations activism, other than the more recent reparations attempts (which I identify as the fifth wave). Tuneen Chisolm identifies the following five waves: the Civil War Reconstruction era; the turn of the twentieth century; the Garvey movement; the Civil Rights movement; and resurging efforts in the wake of the passage of the Civil Liberties Act of 1988 . Tuneen E. Chisolm, Sweep Around Your Own Front Door: Examining the Argument for Legislative African American Reparations, 147 U. PA. L. REV. 677, 683 (1999) (citations omitted).

21 Though the Civil and post-Civil War era is identified as the first major wave, there were indeed pre-Civil War demands for some variant of restitutive and reparative transfers. See GARY B. NASH, THE FORGOTTEN FIFTH: AFrICAN AMERICANS IN THE AGE OF REVOLUTION 147 (2006). Nash notes that in the early nineteenth century, Richard Allen, one of Philadelphia's most prominent black ministers, and his church unanimously endorsed a resolution stating the following:

"Whereas our ancestors (not of choice) were the first successful cultivators of the wilds of America ... we their descendants feel ourselves entitled to participate in the blessings of her luxuriant soil which their blood and sweat manured. ... [A]ny measure ... having the tendency to banish us from her bosom, would not only be cruel, but in direct violation of those principles which have been the boast of the republic."

Id. at $147-48$.

Even earlier, in 1774, Thomas Paine made one of the first calls for AfricanAmerican reparations. Hall, supra note 18, at 17-18.

22 In addition to its colloc uial familiarity, the phrase " 40 acres and a mule" has truly been the rallying cry for historical and modern reparations movements. Citing the reparations movement's deep historical roots, Ogletree reminds us that the movement goes back "at least as far as the unkept promise in 1864 of ' 40 acres and a mule' to freed slaves, which acknowledged our country's debt to the newly emancipated." Charles J. Ogletree, Jr., Op-Ed., Litigating the Legacy of Slavery, N.Y. TIMES, Mar. 31, 2002, § 4, at 9 [hereinafter Ogletree, Litigating the Legacy of Slavery]. 
No. 15. The Field Order directed that each newly emancipated family receive forty acres of land and, as Sherman subsequently authorized, be loaned mules. ${ }^{23}$ Land transfers would be available through the seizure and redistribution of Confederate land. This reparative attempt tracked President Lincoln's belief that emancipated slaves needed land as an economic base for their advancement. ${ }^{24}$ That effort ended in 1865 with the ascendancy of newly elected President Andrew Johnson, who pardoned Confederate sympathizers and restored their property rights. $^{25}$

The second wave, equally unsuccessful, occurred at the turn of the twentieth century when African-Americans, motivated by the abject poverty and racism prevalent in the South, as well as the failure of Reconstruction, organized pension associations and actively lobbied for reparations to ex-slaves. ${ }^{26}$ The third wave occurred decades later during the civil rights movement. Dr. Martin Luther King, Jr., for example, believed that the United States needed to provide reparations before it could hope to free itself from the horrors of its past. ${ }^{27}$ The Black Manifesto, penned by civil rights activists including James Foreman, sought monetary compensation, and also pushed for the reparations effort to be "a call for revolutionary action ... that spoke of the human misery of black people under capitalism and imperialism, and pointed the way to ending those

23 TORPEY, supra note 4 , at 110-11. Land distribution was also seriously debated by the post-Civil War Congress. Both the House of Representatives, led by Congressman Thaddeus Stevens, and the Senate, led by Senator Charles Sumner, pushed both to punish the Confederate states for their treasonous war, and to place the newly freed on the path to economic independence. In re African-American Slave Descendants Litig., 304 F. Supp. 2d 1027, 1059-60 (N.D. Ill. 2004).

24 Verdun, supra note 19, at 601-02.

25 In re African-American Slave Descendants Litig., 304 F. Supp. 2d at 1060. See also TORPEY, supra note 4, at 110-11 (discussing President Johnson's pardon); Verdun, supra note 19, at 600-02 (chronicling the rise and fall of legislation to redistribute Confederate lands to former slaves). After the Civil War, Congressman Thaddeus Stevens, Commissioner Oliver O. Howard, and other members of the Freedman's Bureau called for reparations. Hall, supra note 18, at 18. See also Chisolm, supra note 20, at 685-86; Marvin H. Lett, Opinion, $A$ History of Avoidance, NAT'L L.J., Mar. 6, 2006, for more detailed discussions of the Freedmen's Bureau Acts and the Bureau itself.

26 Verdun, supra note 19, at 602.

27 Anthony E. Cook, King and the Beloved Community: A Communitarian Defense of Black Reparations, 68 GEO. WASH. L. REV. 959, 959 (2000). 
conditions. ${ }^{, 28}$ Although reparations activity was strong during the $1960 \mathrm{~s}^{29}$ ranging from calls for wealth transfer to wholesale revolution, the reparations struggle was subsumed within the much larger civil rights movement. As a result, the post-civil rights reparations campaign subsided in the aftermath of significant legislative advances that came out of the larger civil rights effort.

The passage of the Civil Liberties Act of 1988, which provided an apology and monetary reparations for Japanese-Americans interned during World War II, inspired new efforts for repair. ${ }^{31}$ The late eighties and early nineties produced an independent and determined struggle for reparations for African-Americans in the wake of redress for other racial and ethnic minorities in the Western world, marking the fourth wave of reparations activism. As a result, Democratic Congressman John Conyers made a formal attempt at replicating such legislative success in his 1989 House Resolution on African-American reparations, discussed in greater detail below. ${ }^{32}$

The last six years of race politics have witnessed a new, fifth wave of activism. In response to the unrelenting experience of poverty and lack of access to vital resources for many in the black community, a new and impassioned reparations movement is emerging. ${ }^{33}$ With litigation as the primary vehicle for the

28 TORPEY, supra note 4 , at $112-13$.

29 Verdun, supra note 19 , at 603-04.

30 Author John Torpey has asserted that "the interracial movement that had spearheaded the campaign for those laws and for a larger "beloved community"" also subsided. TORPEY, supra note 4, at 112.

31 Ozer, supra note 18, at 499. See also Shawn Pogatchnik, Idea Reparations: $A$ Proposal to Pay Modern Blacks for Injustices of Slavery Resurfaces, L.A. TIMES, May 28, 1990, at A5 ("The idea [of reparations] regained momentum last year after Congress approved a $\$ 1.25$-billion reparations bill for the 60,000 surviving JapaneseAmericans who were interned without trial during World War II.").

32 See Keels, supra note 19; Robinson, supra note 11 . This resolution was endorsed by the NAACP; the SCLC; the city councils of Cleveland, Detroit, and Inglewood, California; the Council of Independent Black Institutions; the International Association of Black Professional Firefighters; the Association of Black Psychologists; the National Conference of Black Lawyers; and the National Conference of Black Political Scientists. Robinson, supra note 11. In addition, the Chicago-based Caucasians United for Reparations and Emancipation, founded in 1992, and the New York-based National Commission for Reparations, established in 1990, also supported H.R. 3745. Id.

33 According to Charles Ogletree: 
current struggle, contemporary litigants are finding creative means to overcoming the legal hurdles, not the least of which is linking the current economic status quo to past injustices.

\section{Contemporary Arguments for African-American Reparations}

Entities as small as churches and as large as entire international systems have used and continue to use reparations to respond to the atrocities of the past. Claims for AfricanAmerican reparations appeal to remedies in both international ${ }^{34}$

The reparations movement has momentum today because AfricanAmericans have inadequate health care and are more susceptible to disease as a result. All too many are victims of redlining and predatory lending, even though both practices are illegal. Others are denied access to quality education and, as a result, cannot take advantage of opportunities for social mobility. In short, these circumstances have created a frustrated, exasperated, and increasingly angry community that, in ever-increasing numbers, is demanding reparations.

Charles J. Ogletree, JR., All Deliberate Speed: Reflections on the FIRST HALF CENTURY OF BROWN V. BOARD OF EDUCATION 292 (2004), [hereinafter OGLETREe, ALL DELIBERATE SPEED]. The call for a reparations movement is, to Ogletree, for the benefit of "those blacks who did not relocate to the suburbs as a result of integration and who were not lifted up as a result of affirmative action." Id. at 274 .

${ }^{34}$ As a member of the international community, the United States is arguably bound to some form of reparations, as America's past practice of slavery places it well within the obligations of international law. To demonstrate America's obligation with respect to African-Americans, an early reparations scholar, Daisy Collins, cited Article 4 of the Universal Declaration of Human Rights, which was a product of the United Nations General Assembly in 1948. See Ozer, supra note 18, at 482 . Article 4 states that "[n]o one shall be held in slavery or servitude; slavery and the slave trade shall be prohibited in all their forms." Universal Declaration of Human Rights, G.A. Res. 217A, at art. 4, U.N. GAOR, 3d Sess., U.N. Doc A/810 (Dec. 10, 1948), available at http://rwww.un.org/Overview/rights.html. As a signatory of the Universal Declaration, the United States has a unique "obligation to remove all racial inequality for which it is responsible." Ozer, supra note 18, at 483 (citation omitted).

Appeals made to international law hinge on arguments based on slavery and presented as the United States' denial of African-Americans' right to selfdetermination. See Yamamoto, Racial Reparations, supra note 18, at 509-10 n.143. Irma Ozer describes Imari Obadele's alternative argument for the right to reparations:

Imari Obadele posits that the right to accept or refuse the Fourteenth Amendment's offer of U.S. citizenship affords the contemporary African American a new vantage point from which to seek and negotiate for their political and economic objectives, including their reparations rights: Few African Americans became citizens of the United States of their own volition and without duress and, thus, reparations claims based upon 
as well as domestic law. ${ }^{35}$ The claims are grounded in both the indignities of slavery and the postslavery existence for Africans in America.

Typically, the African-American reparationist argues that the uncompensated wrongs in the American context are twofold. ${ }^{36}$ First, there was a failure to pay for slave labor, ${ }^{37}$ specifically, and the contributions slaves made to build the foundation of this society, generally. ${ }^{38}$ Further, slavery as an institution paved the way for the gross inequities that have existed and continue to exist between white and black Americans. In the absence of significant and successful efforts at remedying the condition of the formerly enslaved, the unequal aftermath of slavery remains unsurprising. Consequently, reparations claims involve not just "buried history" but the recent past and present-day reality. Reparationists can cast damages claims in terms of lost wages, property, and economic opportunities occurring in the last

slavery would be best presented in the context of the United States having denied African Americans the right to self-determination.

Ozer, supra note 18 , at 486.

35 See discussion infra Part I.D. Domestic legislatures and domestic courts are the primary fora for the airing of claims. The bulk of the discussion, therefore, focuses on attempts for African-American reparations using American law.

36 Verdun, supra note 19, at 631.

37 In 1619, Dutch traders brought twenty captive Africans to Jamestown, Virginia, Merida, supra note 2, after which followed 246 bloody years of forced servitude, Warren, supra note 3. See also The Case for Reparations: Why? How Much? When?, EBONY, Aug. 2000, at 70 [hereinafter The Case for Reparations] (further discussing the history of the slave trade). By 1825 the population of slaves in America was roughly 1,750,000-a number that made the United States the "leading user of slave labor in the new world." In re African-American Slave Descendants Litig., 304 F. Supp. 2d 1027, 1035 (N.D. Ill. 2004).

Slavery was indeed the dominant economic force in the South. The first of two main causes for this development was that slave labor was relatively inexpensive as compared to other sources of labor. Id. The second major reason was that: "[S]lave masters in the Southern states were willing to expend an 'enormous, almost unconstrained degree of force ... to transform ancient modes of labor into a new industrial discipline.' This 'new industrial discipline' was based on a division of labor scheme, enforced by brutality, and legally sanctioned." Id. (citations omitted). It is very well-documented that the American slave was subject to "abject cruelty, both physical and psychological, by his or her masters in order for the master to maintain domination." Id. at 1036 . One court has described that extreme degree of domination as the "essential crime." Id. (citation omitted).

38 In re African-American Slave Descendants Litig., 304 F. Supp. 2d at 1036.

39 Randall Robinson argues: "We must disinter our buried history, connect it to another more recent and mistold, and give it as a healing to the whole of our people, to the whole of America." The Case for Reparations, supra note 37. 
century. ${ }^{40}$ However, other consequences include high infant mortality, low income, high unemployment, substandard education, capital incapacity, insurmountable credit barriers, high morbidity, below-average life span, and overrepresentation in prison and on death row. ${ }^{41}$ Indeed, reparations is as much based on the bondage of slavery as on the continuing and complex system of black subjugation that merely supplanted slavery. ${ }^{42}$

Second, the psychological harms, that is, the presumption of inferiority, the devaluation of self-esteem, and the myriad emotional injuries that were a necessary component to such subjugation, constitute a great violation committed against African-Americans. ${ }^{43}$ The impact American racism has on the psyches of all, especially African-Americans, is perhaps the most profound remnant of slavery. The psychological impact of slavery is both timeless and significant, such that the argument for reparations due to emotional distress is viable. Black inferiority is inextricably linked to fundamental aspects of

40 See id.

41 Id.

42 See generally DAVID M. OSHINSKY, WORSE THAN SLAVERY (1996) (discussing Parchman Farm and the ordeal of Jim Crow justice); see also Verdun, supra note 19, at 639-40. Verdun writes:

When slavery ended, it was replaced by a caste system designed to maintain the status quo of the previous two hundred and fifty years-white supremacy. ... This wrongful activity, the acts driven by racism to perpetuate white supremacy, is what is being referred to when the term "systemic discrimination" is used.

Id. at 640. In her Thirteenth Amendment reparations analysis, Daisy Collins notes that the unequal position of average black citizens compared to their white counterparts was a direct consequence of slavery. See Ozer, supra note 18, at 484 . For the most part, the freedmen started out without property and experienced vicious discrimination in their efforts to acquire property. Id. Accordingly, Collins bases her theory of remuneration for African-Americans on the imputation that the U.S. government "has deprived its black citizens of property without due process of law. Money is property and is the basic measure of other property." Id. at 485 (internal quotations omitted).

43 Verdun, supra note 19, at 631-33. See also Hall, supra note 18, at 33 (arguing that America had a duty to remedy the past and work to equalize a society that "was more than superficially divided"). Vincene Verdun describes how particularly invidious the substantial divide is and how it works psychologically. She argues, "[a]lthough most whites and African Americans would consciously disclaim any notion that African Americans are inferior to whites, subconsciously many decisions, heavily camouflaged in the cloak of meritocracy, are made based on such beliefs." Verdun, supra note 19, at 634. 
American civilization and culture, ${ }^{44}$ and that inferiority has loomed large..$^{45}$ The calculated annihilation of the slaves' native African culture, the purposeful severing of families by plantation owners, and the slaves' status as chattel have produced an enduring "'slave mentality." 46 Forced servitude and accompanying dehumanization gave birth to this mentality, and the prejudice that is endemic to American society perpetuates it to varying degrees. ${ }^{47}$

To address the uncompensated wrongs discussed above, the first step of three in reparations is for the perpetrator(s) to admit guilt. An apology from the U.S. government and individuals, companies, and institutions that profited from the enslavement of Africans and from their continuing socioeconomic subjugation would be a significant symbolic victory. The remedy phase, the second element, is a critical accompaniment to the apology for sins committed. Most African-Americans, in fact, believe that an apology is meaningless without a "well-funded effort to repair the damage." $" 48$

44 Courtland Milloy argues that black inferiority was a cornerstone of Southern civilization. Courtland Milloy, An Apology Won't Settle This Debt, WASH. POST, June 22, 1997, at B1 (citing the work of historian John Hope Franklin).

45 Vincene Verdun explains:

This heritage of inferiority looms in eerie, ghostlike form over African Americans in the workforce, classrooms, markets, and social circles throughout the nation. It is emotional injury, stemming from the badge of inferiority and from the stigma attached to race which marks every African American, that composes the most significant injury of slavery.

Verdun, supra note 19, at 634-35. Verdun continues by remarking that the dominant culture, within which these claims will be litigated, is blind to this injury. Id. at 635. For reparationists, this is a bleak assessment.

46 Warren, supra note 3 (quoting Charles Kahalifa King).

47 Richard Delgado, acknowledging the psychological effects of racism, takes the diagnosis a step further. See Ozer, supra note 18, at 491-92. Delgado asserts that mental illness, psychosomatic disease, substance abuse, and other antisocial behavior are among the many symptoms of lived racism for persons of color in America. Id. at 492. Even achievement and high socioeconomic status, Delgado contends, do not mitigate the harms of such prejudice. Id. Delgado believes that those who "succeed" cannot fully enjoy the benefits of their status due to uneven and inconsistent treatment of them by others. Id. For more information, see generally Vernellia R. Randall's website, Race, Healthcare and the Law, http://academic.udayton.edu/health/ (last visited Sept. 30, 2007).

48 See Michael A. Fletcher, For Americans, Nothing Is Simple About Making Apology for Slavery; Congressman's Suggestion Draws Fire from All Sides, WASH. POST, Aug. 5, 1997, at A1. African-American leaders have articulated similar sentiments. Jesse Jackson explains: "It is like you drive over somebody with a car, 
In that vein, there has been, for example, a recent, renewed push for disclosure of present-day companies' participation in the slave enterprise. Disclosure laws have sought to inform Americans about the companies they rely on for mortgages, credit cards, and insurance and their role in supporting the slave trade with similar loans. ${ }^{49}$ This push has produced state and local laws demanding such disclosures. ${ }^{50}$ The bases for some

leave the body mangled, then you decide to come back later to apologize with no commitment to help them get on their feet. ... There is something empty in that. It is just more race entertainment." Id.

Though money is consistently cited as a necessary companion to the apology, the amount sought is anything but consistent. The actual monetary award requested as reparations varies as widely as the legal complaints themselves. See generally Ozer, supra note 18, at 498 (describing several of the diverse proposals as to how reparations should be made by various reparationist organizations and conferences). Most, however, believe that U.S. tax revenues should be used to pay reparations. Verdun, supra note 19 , at 653 . Some reparationists have withheld their federal income taxes, Warren, supra note 3, while others like the New Afrikan People's Organization have asked Congress to pay to the political unit of New Afrika nation between $\$ 13$ billion and $\$ 32$ billion per year over a period of years, Ozer, supra note 18, at 498-99. The organization has submitted a "Proposed Act, Rather Than A Constitutional Amendment for Reparations" to Congress. Id. at 498. Under Title I. Reparations, it asks Congress for these annual money allotments. Id.

Similar requests included the Republic of New Africa's 1968 petition to the U.S. State Department for five states and for billions in reparations. Id. And in 1969, the National Black Economic Development Conference produced The Black Manifesto, which announced a plan to demand reparations from white churches and the U.S. government. Id.

Most reparations claims fall in between these two remedies, and for the most part include monetary awards. The claims necessarily reflect the difficulty of putting a "price tag on two and a half centuries of legalized inhumanity." Merida, supra note 2. Emancipation, as Merida points out, brought freedom only, not parity. Id. Most monetary figures have been limited to calculations of wages for unpaid labor. Estimates of present-day values of unpaid black equity in slave labor range from $\$ 48$ billion to $\$ 10$ trillion. Milner S. Ball, Reparations and Repentance: A Response to Professor Cook, 68 GEO. WASH. L. REV. 1015, 1016 (2000). One economist, Larry Neal, adjusted for inflation and calculated a total of $\$ 1.4$ trillion. Merida, supra note 2.

The injuries due to postslavery discrimination have added to this amount. Studies out of the University of California, Berkeley, calculate that the unpaid wages for black workers between 1929-1969, due to unfair treatment and prejudice, total 1.6 trillion present-day dollars. Id.; The Case for Reparations, supra note 37. Further, mortgage and housing discrimination increases the total by $\$ 80$ to $\$ 90$ million. Id.

49 See Darryl Fears, Seeking More Than Apologies for Slavery: Activists Hope Firms' Disclosure of Ties Will Lead to Reparations, WASH. POST, June 20, 2005, at A1.

50 Disclosure ordinances have been passed in Chicago, Detroit, Los Angeles, and Philadelphia. Jeff Jacoby, The Slavery Shakedown, BOSTON GLOBE, June 9, 2005, 
very ambitious reparations litigation have arisen from these disclosures. ${ }^{51}$

There have also been litigation attempts seeking to address discrete assaults on black communities. Today, the Reparations Assessment Group ("Group"), under the leadership of Charles Ogletree of Harvard Law School, is conducting the most prominent reparations campaign. ${ }^{52}$ With the assistance of the late Johnnie Cochran and other legal and political heavyweights, ${ }^{53}$ the Group has been working on lawsuits for the descendants of slaves that they hope will buck roughly 150 years of failed lawsuits and litigation. ${ }^{54}$ Despite early losses, the Group's Coordinating Committee plans to continue to file wideranging reparations lawsuits. This effort, as well as smaller, individual suits, is being aided by the growing public "outing" of companies that profited from slavery and the increasing exposure of the greater black community to the reparations

at A15. Chicago's ordinance gleaned a number of ostensible successes. It requires every company that is currently doing business with the city to investigate and disclose any historical ties it may have had to slavery. Id. As a result of Chicago's disclosure law, J.P. Morgan Chase, the country's second-largest bank, apologized in January 2005 for the role its subsidiaries played in using more than 10,000 slaves as collateral for loans and accepting more than 1000 slaves when their owners defaulted. Fears, supra note 49. Also as a result, Wachovia Corporation promised to make amends by subsidizing the work of organizations involved in "furthering awareness and education of African-American history." Jacoby, supra.

There have also been state and municipal statutes addressing reparations for African-Americans, most notably in Chicago; Rosewood, Florida; California; and Oklahoma. See OGLETREE, ALl DELIBERATE SPEED, supra note 33, at 294-95.

51 See, e.g., In re African-American Slave Descendants Litig., 304 F. Supp. 2d 1027 (N.D. Ill. 2004).

52 Nathaniel Jones describes this effort as perhaps the most serious attempt to get compensation for 244 years of legalized slavery. Nathaniel R. Jones, The Sisyphean Impact on Houstonian Jurisprudence, 69 U. CIN. L. REV. 435, 449-50 (2001).

53 The notable heavyweights include Adjoa Aiyetoro, legal counsel for N'COBRA who joined Ogletree as co-chair, and Manning Marable, professor of history and political science and founding director of the Institute for Research in African-American Studies at Columbia University, as co-chair of the research committee.

54 Doug Hanchett, Lawsuit Planned for Slave Reparation, BOSTON HERALD, Nov. 5, 2000, at 19. Describing the efforts to the Associated Press, Ogletree remarked: "We will be seeking more than just monetary compensation .... We want a change in America. We want full recognition and a remedy of how slavery stigmatized, raped, murdered and exploited millions of Africans through no fault of their own." Id. 
movement. ${ }^{55}$ As discussed below, however, African-American reparations claimants have significant, perhaps insuperable, social, political, and jurisprudential hurdles to leap.

The struggle for African-American reparations reflects a larger cultural conflict, ${ }^{56}$ in which the dominant perspective influences the very systems in which African-Americans seek repair. This perspective is highly relevant to the present discussion, because those who subscribe to or unknowingly employ the dominant perspective and those who do not often differ along racial lines as well.

The dominant perspective is the property of the dominant group. The dominant group generally consists of white Americans, ${ }^{57}$ members of American society who most often view themselves as objective actors. ${ }^{58}$ Individualism and self-

55 For information on the outing of insurance companies that issued policies to slave owners to protect them against the loss of their slaves, see generally Slave Insurance Policies Uncovered: The Call for Reparations, http://afroamhistory .about.com/library/weekly/aa120400a.htm (last visited Sept. 30, 2007). Evidence of greater interest and awareness within the black community itself has been cited in the recent workshops on the topic held during the 2005 national NAACP convention. See Keels, supra note 19. A cruder indicator is the Hip Hop Summit Action Network's plans for a publicity campaign based on the theme of "Forty Acres and a Bentley." Bankrolled by hip-hop magnate Russell Simmons, it was meant to include the luxury car that Simmons admits "has become the highest American aspiration for this generation, unfortunately."' TORPEY, supra note 4, at 126.

56 This is indeed a culture war. See, e.g., Alfred L. Brophy, Reparations Talk in College, 11 MICH. J. RACE \& L. 195, 203 (2005) ("Reparations, as Horowitz observes, is part of a culture war." (reviewing DAVID HOROWITZ, UNCIVIL WARS: THE CONTROVERSY OVER REPARATIONS FOR SLAVERY (2002))).

57 Verdun, supra note 19, at 610 . Verdun explains that the dominant perspective is not necessarily race-, class-, or even gender-specific. It is more likely, however, that a white, heterosexual, middle-class, Christian man has been indoctrinated by the values and norms of the dominant perspective, certainly more so than a poor black woman. Id. at 610 n.35.

58 Carter, supra note 12, at 1024. According to Carter, viewing themselves as objective actors, white Americans believe that they are immune to considerations of race. Id. Further, "many whites emotionally reject the idea that they could be thinking in such a way that elevates whiteness." Id. From the dominant perspective, the "dominant narrative" emerges. Id. at $1027 \mathrm{n} .22$. The "dominant narrative" produces a body of "received wisdoms that pass as truth but actually are contingent [and] power serving." Id. (quoting Richard Delgado, Rodrigo's Final Chronicle: Cultural Power, the Law Reviews, and the Attack on Narrative Jurisprudence, 68 S. CAL L. REV. 545, 549 (1995)). The narrative known as truth is supported by the belief that people are instinctively self-centered, and the goals, opinions and identity of the individual are primary in all analysis. See id. at 1025 (citing sociologist Gordon Allport's analysis of people's primary motivations). 
determination are the cornerstone principles of the dominant perspective. ${ }^{59}$ Consistent with these principles, this perspective understands systemic maladies as isolated and the result of aberrations in individual characters or discrete instances. ${ }^{60}$

African-Americans, on the other hand, have a different perspective that has a greater communal emphasis. ${ }^{61}$ For African-Americans, generally, there is a positive expectation that one member's success will be felt and enjoyed by other African-Americans. ${ }^{62}$ The individual is subordinate to "group

59 Verdun, supra note 19 , at 619 . The dominant perspective inherits much of its philosophy from liberalism. Relevant to this discussion, Mari Matsuda describes the connection between "liberal legalism" and the classical liberal political tradition. Liberal legalism refers to both "the ideology of liberalism (exemplified by individual rights, procedural fairness, equality and liberty) and the correlative commitment to legalism (an appeal to legal reasoning and the rule of law as somehow logical, coherent and determinant)." Mari J. Matsuda, Looking to the Bottom: Critical Legal Studies and Reparations, 22 HARV. C.R.-C.L. L. REV. 323, 362 n.159 (1987). Of the connection, Matsuda notes Karl Klare's assertion that:

Liberal legalist jurisprudence and its institutions are closely related to the classical liberal political tradition, exemplified in the work of Hobbes, Locke and Hume. The metaphysical underpinnings of liberal legalism are supplied by the central themes of that tradition: the notion that values are subjective and derive from personal desire, and that therefore ethical discourse is conducted profitably only in instrumental terms; the view that society is an artificial aggregation of autonomous individuals; the separation in political philosophy between public and private interest, between state and civil society; and a commitment to a formal or procedural rather than a substantive conception of justice.

Id. at 362-63 n.159. For additional discussion of the effect of liberalism on the reparations debate, see generally Cook, supra note 27.

60 See Verdun, supra note 19, at 619.

61 Not only do African-Americans happen to have a different perspective, the dominant perspective is threatening in more invidious ways. Anthony Cook explains:

The illusion of self-creating and free individuals, whose group identity is dynamic and fleeting, imprisons the subordinated in a world that appears free, but everywhere has them in chains. ... The dominant group supplies the cultural material of self-creation, which we believe ourselves to choose freely and mold to our will. Unwittingly, the cultural material provided preforms our sense of beauty, intelligence, right and wrong. Only the critically conscious can free themselves from these invisible chains and the matrix of conditioned beliefs that hold them as spiritual prisoners of war.

Cook, supra note 27, at 970.

62 Verdun, supra note 19 , at 627 . Verdun describes this as a "kinship through race" that fuels the expectation that successful members will give back. Id. 
orientation." ${ }^{\prime 63}$ Conversely, whereas the reparationist might view the reparations struggle as a benefit for the entire black community and an opportunity for the larger American society to face its living history, the dominant perspective views the struggle as wholly different-an organized shakedown for undeserved individual payouts.

Furthermore, according to the dominant perspective, culpability cannot and should not sully an entire group. ${ }^{64}$ This perspective understands the reparations struggle only as (perhaps) a baseless affront on innocents by questionable claimants. Again, to the dominant group, the absence of true perpetrators or clear victims is dispositive. According to the dominant perspective, twenty-first-century America is wholly faultless with respect to its long history of racial dysfunction, and should proceed with impunity. Because American legal and political systems are a product of the dominant group, those systems have been necessarily hostile to the claims made by African-Americans for reparations. It is important, therefore, to understand the practical obstacles African-Americans have faced in the courts as well as in the legislature.

\section{The Viability of African-American Reparations Claims: Contemporary Reparations in Context}

\section{Obstacles in American Jurisprudence}

One belief that is universally espoused in the American narrative, even by subscribers to the dominant perspective, is the need to make whole those that have been wronged by racial discrimination. ${ }^{65}$ Even the most ardent opponents of remedial

63 Id. at 625 (citing ROBERT STAPLES, INTRODUCTION TO BLACK SOCIOLOGY 78 (1976)).

64 Id. at 630 . Verdun explains:

From the dominant perspective, it would be patently unfair to make all white people or society pay for slavery because that would necessarily include people who did not participate in the wrong....

A claim for compensation based on slavery ... . would imply that all African Americans were injured by slavery and that all white Americans caused the injury or benefitted from the spoils of slave labor.

Id.

65 Even, and perhaps especially, conservatives espouse this belief. In fact, in his article Taking Conservatives Seriously, Kim Forde-Mazrui argues that conservative 
methods, such as affirmative action, are enthusiastic advocates of repair for individuals that have allegedly suffered at the hands of those affirmative methods. ${ }^{66}$ The argument for these opponents, and certainly for reparations activists, is based on the moral principles of addressing the impacts of racial discrimination, as well as the notion of corrective justice. ${ }^{67}$ Corrective justice describes the principle that one who harms another by wrongful conduct is obligated morally to make amends to the injured party. With respect to racial discrimination, therefore, corrective justice dictates the following: "To the extent society participated in wrongful discrimination, society is arguably obligated, as a matter of corrective justice, to make amends to

opposition to remedial policies, such as affirmative action and arguably reparations, is based on the very principles that militate in favor of such policies, "as much as and arguably more than they counsel against them." Kim Forde-Mazrui, Taking Conservatives Seriously: A Moral Justification for Affirmative Action and Reparations, 92 CAL. L. REV. 683, 686 (2004).

${ }^{66}$ Forde-Mazrui notes the uncanny parallel between conservatives' reasoning for repair in the case of affirmative action and those of African-Americans vis-à-vis affirmative action and, correspondingly, reparations. He writes:

Opponents of affirmative action further contend that the victims of racial preferences should be made whole. Thus, for example, when a public university denies admission to a white applicant because of her race, that applicant has been injured by immoral state-sponsored conduct and should be accorded a remedy, such as monetary damages or injunctive relief by the offending state.

Id. at 691 .

As further evidence of this parallel, Forde-Mazrui cites language from Justices Scalia and Kennedy, who have a record of opposing affirmative action efforts. See Adarand Constructors, Inc. v. Pena, 515 U.S. 200, 239 (1995) (Scalia, J., concurring in part and concurring in the judgment) ("Individuals who have been wronged by unlawful racial discrimination should be made whole") (quoted in Forde-Mazrui, supra note 65, at 691 n.24); City of Richmond v. J.A. Croson Co., 488 U.S. 469, 518 (1989) (Kennedy, J., concurring in part and concurring in the judgment) ("[T]he State has the power to eradicate racial discrimination and its effects in both the public and private sectors, and the absolute duty to do so where those wrongs were caused intentionally by the State itself.") (quoted in Forde-Mazrui, supra note 65, at 692 n.24). Forde-Mazrui uses these instances to support his thesis "that principles central to arguments made against affirmative action support as much as negate a societal obligation to remedy effects of past racial injustice." Forde-Mazrui, supra note 65 , at 690 .

By relying on the principles passionately endorsed by conservatives, FordeMazrui convincingly "reveal[s] the contradictory implications of claims about the wrongfulness of racial preferences." Id. at 693 . In doing so, he hopes to "persuade more moderate observers that, on balance, America's moral obligation to repair her wrongful history outweighs the moral costs of doing so." Id.

67 Id. at 692. 
the victims thereof." ${ }^{\prime 8}$ Further, according to corrective justice theory, withholding remedies for past discrimination would allow those injustices to remain uncorrected, which in and of itself constitutes a moral wrong. ${ }^{69}$

Mainstream America, as well as the courts and the legislature, resists African-American claims, however, because of their departure from individual victim and individual perpetrator models of litigation. ${ }^{70}$ While litigating vigorously on behalf of monetary compensation is perhaps the most mainstream of American activities, ${ }^{71}$ the governing theories at the base of America's judicial system allow little justification for AfricanAmerican claims for reparations. There are three primary theories that I will address here, and then I will identify a few others that also present significant obstacles.

\section{a. The "No Benefit from Another's Wrongdoing" Theory}

First, the "no benefit from another's wrongdoing" theory of culpability fails in American jurisprudence. ${ }^{72}$ In other words, arguments based on the belief that American society was

$68 \mathrm{Id}$. This is the moral case that is used by opponents of affirmative action. Forde-Mazrui argues persuasively that this also supports a moral case in favor of affirmative action as a remedial method of addressing the impacts of racial discrimination against African-Americans historically. Id.

69 Id.

70 Yamamoto, Racial Reparations, supra note 18, at 488-89 (arguing that the courts and mainstream America are unwilling to accept the group victim/group perpetrator proposition). But see Ozer, supra note 18, at 487 (describing Boris Bittker's claim that Congress is, in fact, a better body with which to contemplate redress (citing BITTKER, supra note 18, at 84-85)). A legislative body has greater discretion, whereas a court is limited to remedies for the parties before it and those "similarly situated." Id. Congress, Bittker explains, has virtual plenary power to establish a program for black reparations by exercising its authority under the General Welfare and Commerce Clauses, and Section 5 of the Fourteenth Amendment. Id. However, as I discuss later, Congress is similarly stymied by the pervasive "dominant perspective" and its (often) accompanying racism. See infra Part I.D.2.

${ }^{71}$ Indeed, it is at the very base of our jurisprudence. One recipient of JapaneseAmerican reparations "regarded the monetary compensation as appropriate, arguing that "the jurisprudence system in the US says: "You violate someone's rights, you pay." Although the quest for financial reparations is frequently dismissed as a peculiarly 'American' malady, others also see monetary compensation as a means-however inadequate- of making amends." TORPEY, supra note 4, at 93 .

72 John A. Robertson, Ethics and Policy in Embryonic Stem Cell Research, 9 KENNEDY INST. OF ETHICS J. 109, 113 (1999). 
unjustly enriched at the expense of African-Americans are not persuasive nor do they militate in favor of any manner of redress. This sort of complicity theory is far too broad to operate as a guiding principle of moral or social practice. ${ }^{73}$ If one were to remain true to the "no benefit" principle it would be difficult to live in the modern world. It is believed that many common activities, practices, and social arrangements are traceable to some past wrongdoing in American society. Understanding the taint that is common to the entire modern world, modern jurisprudence dismisses this theory due to its very impracticability.

\section{${ }^{73}$ Id. John Robertson argues:}

If taken seriously, it would mean that the taint of an original alleged immoral action, no matter how attenuated, could never be removed as long as it were still traceable to the original action. Such a view would make us all morally complicit in any immoral action that at several removes still underlies or contributes to economic and social transactions from which we benefit.

Id.

74 Robertson uses the wresting of land from Native Americans as an example. Id. at 114 .

75 Robertson cites the U.S. Supreme Court holding in Massachusetts v. Feeny, 442 U.S. 256 (1979), in which the Court decided past discrimination against women by the military does not render state preferences for veterans for civil service jobs discriminatory under the Fourteenth Amendment. Robertson, supra note 72, at 133 n.4. The Court's equal protection jurisprudence rejects the "benefit from" view of past racial and gender discrimination in its assessment of race- or gender-neutral public policies that have a disproportionate or disparate racial or gender impact. Id.

Professor W. Burlette Carter argues that this rule is far from hard and fast. In fact, the United States, to its benefit, has employed the alternative. She argues that the United States has demonstrated that it can and will allow for exceptions to established conceptions of entitlement and individual responsibility when those exceptions are in the majority's interests or, at least, not significantly to its detriment. Carter, supra note 12, at 1030-31. She further argues that American law has "long reached beyond the direct perpetrator," allowing the circle of crime and remedy to include those who knowingly take advantage of the "spoils" of a perpetrator's wrongful conduct, irrespective of a direct relationship to the perpetrator. Id. at 1029.

There are also deep and compelling concerns about the crude quantification that is part and parcel of an unjust enrichment claim. An unjust enrichment claim seeks to compel the restitution or recompense of a benefit unjustly and/or illegally acquired. In many of the contemporary reparations cases brought to federal court, see, e.g., In re African-American Slave Descendants Litig., 304 F. Supp. 2d 1027 (N.D. Ill. 2004), reparationists argue that the unjust enrichment argument provides "at least a modest measure of what is owed." Brophy, supra note 56, at 208. This argument is undercut, however, because of its perpetuation of the person-asproperty idea-a shortcoming that should not be taken lightly. It appropriates a 


\section{b. The Theory of Causation}

The theory of causation also poses a significant obstacle for reparations claims. Causation requires simply a nexus between an identifiable act and an injury to an individual or community of individuals that logically derived from that act. ${ }^{76}$ Like the "no benefit" argument, the perpetrator's commission and the victim's experience of the initial harm must have temporal and circumstantial boundaries to be reasonably justiciable. Further, in the context of harms claimed by African-Americans, causation-here, that past captivation and enforced discrimination that produced certain contemporary conditions for African-Americans-must serve more than a descriptive role; rather, it must serve as a demonstration of society's responsibility to African-Americans. ${ }^{77}$ In this respect, AfricanAmericans face an insuperable barrier. The theory of proximate cause dictates that "causation-in-fact does not necessarily establish responsibility, particularly for subsequent events that result more immediately from intervening voluntary choices." ${ }^{\text {, }}$ The intervening choices of African-Americans, real or perceived, will necessarily vitiate any claims that might comfortably fit into the causation model.

method of the dominant culture that, at best, muddies the moral claims, and at worst, wholly destroys those moral claims by commodifying the wrong.

76 The rationale is as follows:

In a philosophical sense, the consequences of an act go forward to eternity, and the causes of an event go back to the dawn of human events, and beyond. . . . Some boundary must be set to liability for the consequences of any act, upon the basis of some social idea of justice or policy.

Verdun, supra note 19, at 621 n.67 (quoting W. Page KeEton Et Al., Prosser AND KEETON ON THE LAW OF TORTS \$41, at 264 (5th ed. 1984)).

77 See Forde-Mazrui, supra note 65 , at 730.

$78 \mathrm{ld}$.

${ }^{79}$ Forde-Mazrui makes a novel argument as to the continuing responsibility of American society that is consistent with causation theory. He argues that "[t]o the extent corrective justice bases responsibility on the causal agent's fault, the foreseeability inquiry appropriately focuses on what the wrongdoer should have anticipated as a consequence of his wrongful acts." Id. at 733 . Fairness considerations factor in such that responsibility for intentional wrongdoing may extend to unforeseen consequences. Id. at 733-34. The severity of the harm committed by the wrongdoer will dictate the extent to which that person should be heard to be complaining that the harm committed was not intended or foreseeable. See id. Forde-Mazrui applies this argument to the claims brought by AfricanAmericans: 


\title{
c. Statutes of Limitations
}

Objections to remedies based on statutes of limitations have effectively foreclosed any hopes of successful litigation, or even adjudication on the merits. American jurisprudence is suspicious of stale injuries, particularly injuries that may have occurred well over 140 years ago. ${ }^{80}$ The statute of limitations serves the purpose of ensuring that the action is brought when the evidence is still fresh. This primary purpose comports with the notion that the "passage of time is, in general, a reliable proxy for the increased complexity of events." 81

\begin{abstract}
[T] he question is not whether the conduct of poor blacks would be foreseeable if carried out by those Americans who have not experienced the effects of societal discrimination. The question, rather, is whether such conduct reflects a predictable response by those most acutely impacted by discrimination, those whose lives confront the full catastrophe of America's discriminatory history. If we sincerely endeavor to appreciate the nature and influence of past discrimination, we should recognize that the choices of so many black Americans have been and continue to be shaped by the intergenerational effects of class and caste.
\end{abstract}

Id. at 734-35. Here, "class effects" signal the "conditions derived primarily from economic deprivation that tend to impair the opportunities of present and future generations." Id. at 735. "Caste effects," by contrast, are broader in scope and refer to "social status-based discrimination that goes beyond the immediate disadvantages of poverty." Id.

80 See Yamamoto, Racial Reparations, supra note 18, at 491 . With respect to the statute of limitations issue, Carter identifies an alternative in the criminal law. She argues that if slavery can be considered a crime against society, as well as individuals, there is no statute of limitations that can bar a remedy. Carter, supra note 12, at 1029 n.36. Two questions arise, however. The first, which Carter identifies, is the problem of identifying an appropriate remedy available under criminal law. Id. The second is the issue of legality. Many opponents to reparations argue that slavery was a legal institution in its time, rendering it above criminal status.

Additionally, Mari Matsuda makes an interesting and potentially helpful counterpoint, based on a continuing harm argument. She writes, "[r]eparations claims are based on continuing stigma and economic harm. The wounds are fresh and the action timely given ongoing discrimination. Furthermore, the injuries suffered-deprivation of land, resources, educational opportunity, personhood, and political recognition-are disabilities that have precluded successful presentation of the claim at an earlier time." Matsuda, supra note 59, at 381-82.

Finally, tying elements of these two themes together, Forde-Mazrui argues that the claims based on slavery, and on the subjugation of African-Americans that followed emancipation, have a moral component that makes them timeless based on equitable grounds. Forde-Mazrui, supra note 65, at 738-39. Appealing to the theories of equitable estoppel and equitable tolling, a court should find that a claim is not barred despite the passing of the statutory limitations period. Id.

81 Richard A. Epstein, The Case Against Black Reparations, 84 B.U. L. REV. 1177,1185 (2004). 
Another purpose is to bring closure to past disputes. ${ }^{82}$ Those forwarding the statute of limitations defense, generally reparations detractors, can conceive of political and legal exigencies that in fact barred the bringing of claims earlier in time. "It takes little imagination," Richard Epstein explains, "to accept that the statute should be tolled when the injured person is prohibited by law from bringing any legal action at all, which occurs when a slave is a nonperson." ${ }^{83}$ However, for many, that rationale for tolling does not extend beyond 1865 , the year of emancipation. Though detractors like Epstein will admit that segregation was a period of severe injury, they would not toll the limitations period "because segregation did not limit the right to bring suit, even if the climate of opinion made it impossible to win on these cases. ${ }^{\prime 84}$ For the individualist of the dominant perspective, the "truncation worked by the statute of limitations prevents these reparations actions from lasting for more than a single generation." ${ }^{25}$ Absent that truncation, the legal system would be forced to "contrive" some class payment that goes to nameless, faceless individuals who purportedly represent those harmed. ${ }^{86}$

\section{d. Other Legal Obstacles}

In addition to the litigation pitfalls discussed above, other legal hurdles include the absence of directly harmed individuals, the absence of individual perpetrators, and the indeterminacy of compensation amounts. However, and perhaps most significantly, any basic attempts at challenging the dominant

82 Id. at 1183 .

83 Id. at 1184 .

84 Id. This unfailing devotion to the limitations period even leads to some convoluted and contrived calculations attempting to prove just how complicated the action would be some seven generations after 1865. Epstein reasons, "[i]n the years since 1865 we have had at least seven generations, so that a direct descendant of a slave is 127 parts not slave descendant, unless there is another slave somewhere else in his or her line of ascent." Id. at 1185 . Epstein's calculations are sloppy conjecture. The fact that most of those descendants were legally barred in many places from marrying outside of this group of descendants, for example, appears not to have figured into his calculus. To assume that there were no descendants born of parents that were both slaves, on down to subsequent generations, is patently illogical and unreasonable.

85 Id. at $1185-86$.

86 Id. at 1186. 
group and its accompanying culture and perspective are discouraged, if not wholly prohibited. Group identification, in spite of its many advantages in the case of African-American reparations litigation, ${ }^{87}$ is a direct threat to individualist tenets. ${ }^{88}$

Ultimately, the primacy of the individual is critical to American jurisprudence. ${ }^{89}$ Rights are afforded to the individual above groups or communities; ${ }^{90}$ and any departure from that legal norm could do great violence to American jurisprudence. While the law and the legal process have the potential for revolutionary and transformative effects, ${ }^{92}$ the judiciary, true to

87 According to Milner Ball, there are three advantages to group rights: (1) they avoid litigation's limiting focus on individual injury; (2) they help to overcome our cultural fixation on individualism that "troubles" black-white relations; and (3) they enjoy some precedent in reparations for Japanese-Americans in this country and for Jews in Europe. Ball, supra note 48, at 1018.

88 See Cook, supra note 27 , at $970-71$.

89 To some commentators, this is no accident. Carter writes: "That the culture has only words for claims or injuries that a free white person might also possess or endure is not accidental-the limitation in language is a product of the oppression itself." Carter, supra note 12, at 1032.

90 In the law of torts, for example, "[i]ndividualism, the big 'I,' is pervasive in this scheme of liability." Verdun, supra note 19, at 620 . With respect to the reparations argument most will respond simply: "If ' $I$ ' did not do anything wrong, then 'I' should not have to pay for the wrong." $I d$. The liability premise, and the supremacy of "I," is so central to American legal doctrine that departure from individualist principles to remedy historical group harm would threaten this longstanding doctrine.

91 Robert Cottrol argues: "This individualistic approach cannot be lightly set aside without doing violence to much of American constitutional doctrine, doctrine that has been painfully achieved over the course of two centuries." Robert J. Cottrol, A Tale of Two Cultures: Or Making the Proper Connections Between Law, Social History and the Political Economy of Despair, 25 SAN DIEGO L. REV. 989, 1021 (1988), quoted in Verdun, supra note 19, at 624 n.85. Cottrol goes on to warn:

And yet, a too rigid adherence to this individualistic model will leave American government and society with little ability to deal with the cultural devastation that has occurred in America's inner cities. Courts presented with this question seem to have a Hobson's choice of either permitting what appears to be an assault on the concept of individual rights or precluding measures that can break down long-term cycles of exclusion.

Id. Reparations cases based on slavery and its legacy are not only unpalatable but culturally and, for that reason, doctrinally hazardous.

92 Eric Yamamoto writes:

The ... law and legal process, independent of formal outcome, can serve as generators of "cultural performances." They can provide an institutional public forum for calling powerful government and private actors to account. They can offer opportunity to develop and communicate counter- 
its governing norms has thwarted these efforts in the reparations arena. Some courts have paused to regretfully note the limitations of the legal system to a degree. ${ }^{93}$ All courts, however, have stood faithfully by these limiting theories.

\section{Obstacles in American Legislation}

Courts have been consistent in their hostility towards reparations plaintiffs; however, the legislature, where a political answer could be found, is arguably an even more hostile terrain in which to address these grievances because it is governed by the mainstream.

narratives to prevailing stories about minority communities. And they can help focus community education and political organizing efforts.

Yamamoto, Racial Reparations, supra note 18, at 509-10.

93 See, e.g., In re African-American Slave Descendants Litig., 304 F. Supp. 2d 1027,1075 (N.D. Ill. 2004). Upon dismissing plaintiffs' claims, effectively destroying any hopes of redress of the claimants, the court states defensively:

Some may view this ruling as a condonation of ancient wrongs. That view is wrong. To suggest that the lions have won again and that the court is impervious to the human suffering at the core of this case would be absurd. The reasonable prudent person will read this opinion with care. We strive, case by case, within an imperfect system of law, through human endeavors, towards the unattainable perfect justice we seek.

Id. With somewhat less sympathy, the Tenth Circuit in Alexander v. Oklahoma, notes that several earlier suits were filed seeking redress for property and other losses suffered during the Tulsa Riots. 382 F.3d 1206, 1218 (10th Cir. 2004). The plaintiffs acknowledged the successful filing of these suits, including one that reached the Oklahoma Supreme Court in 1923, yet maintained that the complaints were futile and did not yield a single recovery for the African-American claimants. Id. In response to the futility of these actions, the court states: "While that is true, and certainly tragic, it is not relevant to the narrow issue presented here: whether the District Court abused its discretion in finding, based on undisputed evidence, that Defendants' alleged concealment did not bar Plaintiffs from uncovering essential information about their claims." Id.

94 While invoking the legal limitations, the courts have remained loyal to the cultural precursors of the law. See, e.g., In re African-American Slave Descendants Litig., 304 F. Supp. 2d at 1070 (dismissing case brought on behalf of slave descendants finding, among other things, the claims to be time-barred); Cato v. United States, 70 F.3d 1103, 1109 (9th Cir. 1995) (holding that, "[w]ithout a concrete, personal injury that is not abstract and that is fairly traceable to the government conduct that she challenges as unconstitutional," plaintiff lacked standing); see also Johnson v. McAdoo, 45 App. D.C. 440, 441 (D.C. Cir. 1916) (dismissing case on grounds of sovereign immunity). 
Several reparations analysts argue that the legislature is the more favorable arena in which to stage the struggle. ${ }^{95}$ Indeed, the legislature is perhaps the only remaining branch of government before which African-Americans can press their claims. ${ }^{96}$ And since the late eighties, with the awarding of reparations to the Japanese-Americans, Congress has been a somewhat lively arena for the reparations discourse. The two major efforts have both been House Resolutions, one sponsored by John Conyers, the other by Tony Hall.

On November 20, 1989, Representative John Conyers (DMI), a ranking Democrat, dean of the Congressional Black Caucus ("CBC") and, at that time, a twenty-five-year veteran of Capitol Hill, introduced H.R. 40," "Commission to Study Reparation Proposals for African-Americans Act." ${ }^{98}$

95 See, e.g., BITTKER, supra note 18; Hall, supra note 18, at 20 (arguing that congressional efforts are more promising than courts); Note, Bridging the Color Line: The Power of African-American Reparations to Redirect America's Future, 115 HARV. L. REv. 1689, 1692-94 (2002) [hereinafter Bridging the Color Line] (claiming that group rights and remedies are best vindicated through legislation: "The only political branch powerful enough to step legitimately outside the individual rights paradigm to bring the entire polity into the debate and provide remedies that will rebuild institutions or change the dynamics of social relationships is Congress.").

96 See, e.g., Epstein, supra note 81, at 1187 ("The elimination of all legal avenues of relief will, we can be confident, place great emphasis on political efforts to achieve the same results."); Allen C. Guelzo, Editorial, Dismissal Could End the Drive, RICHMOND TIMES-DISPATCH, July 20, 2005, at A10. In dismissing the case In Re African-American Slave Descendants Litig., the court, according to Guelzo:

[D]oes not deny that slavery was an act of inhumanity, nor does it preclude a Conyers-style commission from investigating reparations for postemancipation harms, or endorsing the creation of a national black educational fund, or the adoption by Congress of a national apology for slavery.

... [I]t would be hard to imagine a gesture that carries more symbolic punch than an endorsement of the Conyers bill, which has languished in committee for more than a dozen years.

Id.

97 For additional discussion of the history of the Conyers bill, see Hall, supra note 18, at 19-22; Chris K. Iijima, Reparations and the "Model Minority" Idealogy of Acquiescence: The Necessity to Refuse the Return to Original Humiliation, 19 B.C. THIRD WORLD L.J. 385, 388-89 (1998); Verdun, supra note 19, at 659-67; Yamamoto, Racial Reparations, supra note 18, at 511-15; Legislative Watch, HUM. RTS. BRIEF, Winter 2001, at 17. Merida, supra note 2; The Case for Reparations, supra note 37.

98 A relatively benign proposal, the commission would consist of historians, legal scholars, genealogists, economists, and lawmakers, charged with the task of drafting a report regarding the issue of reparations for slavery and its legacy. Legislative 
Unsuccessful in 1989, the Congressman has, like clockwork, introduced this bill each successive year to no avail. Though the bill seeks only to study the possibilities of reparations and is not a request, it has not made it out of congressional committee in its seventeen years of renewed introduction.

In June 1997, Congressman Tony Hall (D-Ohio), a white representative from a predominantly white district, introduced legislation calling for a one-sentence apology to AfricanAmericans.99 Hall viewed this simple gesture as one of moral propriety and "“conscience in the effort to advance race relations.", ${ }^{100}$ Hall explained, "It is a step toward healing. That's all it is, a simple apology. ...",101

The response to Hall's bill was "fiery," 102 however, and he abandoned the proposed legislation as a result. According to one poll, sixty percent of white Americans disfavored the legislation and that opposition was often accompanied by harsh

Watch, supra note 97 , at 17 . The seven-member committee would, among other things, examine slavery in America between 1619 and 1865, determine if the U.S. government should apologize on behalf of the American people for the human rights abuses perpetrated against African slaves and descendants, and decide whether or not compensation to the descendants of slaves is warranted. Id. Additional points of interest include the treatment of African slaves during the middle passage and their movement within the United States; the federal and state governments' roles in supporting slavery and opposing repatriation efforts for freed African slaves; discriminatory laws dating from the Civil War; and the continuing effect of slavery and discrimination on African-Americans today. Id.

"'This is not a witch hunt," Conyers once explained. The Case for Reparations, supra note 37. "We are not looking for people who owned or traded in slaves. And we're not trying to penalize people for things that happened in another century." Id. Conyers's bill is meant to handle the issue of reparations with the purpose of enlightening and healing, rather than placing blame or further dividing the country racially.

99 The text of the resolution read as follows: "Resolved by the House of Representatives that the Congress apologizes to African-Americans whose ancestors suffered as slaves under the Constitution and the laws of the United States until 1865." H.R. Con. Res. 96, 105th Cong. (1997). For additional discussion, see Hall, supra note 18, at 24-25; Yamamoto, Racial Reparations, supra note 18, at 511-13; Fletcher, supra note 48; Merida, supra note 2.

100 Merida, supra note 2.

101 Fletcher, supra note 48. Hall concludes that statement somewhat hopefully, stating: "'Someday it will happen. I just don't see it happening anytime soon." Id.

102 Merida, supra note 2. During a 60 Minutes interview in 2001, Hall noted that he had never received so much hate mail. Lett, supra note 25. See also Yamamoto, Racial Reparations, supra note 18, at $523 \mathrm{n} .151$ (noting that Hall received hundreds of letters and phone messages, most of which condemned his resolution). 
racial language. ${ }^{103}$ Some claimed that Hall was stirring racial anger by resurrecting "dead" history. ${ }^{104}$ One man wrote to Hall insisting that the government should apologize to him for stripping his great-grandfather of his 435 slaves. ${ }^{105}$. Another wrote that African-Americans should be thankful that slave traders rescued their ancestors from Africa.

From this, two common arguments emerged. The first was that of the immigrant who claimed no connection to or benefit from slavery; and the second was a belief that America has done more than enough to atone for slavery with the loss of more than 350,000 Union soldiers in the Civil War, ${ }^{106}$ the introduction of affirmative action, and civil rights legislation. ${ }^{107}$

In response to this public outcry, Hall stated: “'I don't know that we'll ever apologize while I'm in Congress . . . because I'm not sure the country is ready for it. I couldn't believe the hate and anger that came about because of it." ${ }^{108}$ In the end, Hall acknowledged: "IIf we can't do something as simple as saying we're sorry, we've got a long way to go."'109 It is clear, however,

${ }^{103}$ Fletcher, supra note 48. A 1997 Gallup Poll also found that two-thirds of white Americans opposed the idea of a congressional apology while two-thirds of African-Americans support it. Id. Other polls suggest similar differences between black and white Americans regarding the reparations question. See Fears, supra note 49 (noting that a CNN/USA Today/Gallup poll in 2002 showed that nine out of ten white Americans said the government should not make cash reparations payments, while half of black respondents said it should. Sixy-two percent of white respondents also believed that the government should not apologize to AfricanAmericans for underwriting slavery, while $68 \%$ of African-Americans said it should); see also James R. Hackney, Jr., Ideological Conflict, African American Reparations, Tort Causation and the Case for Social Welfare Transformation 84 B.U. L. REV. 1193, 1203 (2004) (citing one study that found that only $4 \%$ of white Americans believed reparations should be paid).

104 Merida, supra note 2.

105 This example and those that follow are found in Fletcher, supra note 48.

106 Roughly 620,000 Americans died in the Civil War; Union forces fighting to end slavery suffered 360,000 of these deaths. In re African-American Slave Descendants Litig., 304 F. Supp. 2d 1027, 1037 (N.D. Ill. 2004). But there were also significant fatalities suffered by African-American soldiers. "There were 178,975 African-American Union troops that fought in the Civil War, and 36,000 of those troops died during the war." Id.

107 Fletcher, supra note 48. Fletcher quotes political scientist Andrew Hacker, who remarks: "People say, '[w]e have done everything we have to do. We had affirmative action. We supported civil rights. Don't call us anymore.' I sense a lot of that feeling out there." Id.

108 Merida, supra note 2.

109 Fletcher, supra note 48. 
that not only is America not prepared to say "sorry," it is at the same time riddled with racial animosity and severe cognitive dissonance with respect to both its distant and more recent past. $^{110}$

\section{II}

\section{REDEFINING OUR TERMS}

In spite of the political and legal environment in which African-Americans seek to remedy their claims, the AfricanAmerican reparations discourse remains preoccupied with the first two elements of reparations campaigns. ${ }^{111}$ Apology, as evidenced in singular legislative attempts, and monetary awards, sought through myriad litigation efforts, are non-starters for the large-scale transfers sought by African-American reparationists. They are dead ends because American jurisprudence and the American dominant culture, expressed through its legislature, cannot and will not recognize these claims. It is essential, therefore, that in seeking repair, African-American reparationists consider the third element of nonrepetition in order to construct a society in which their claims can even be heard. In other words, in seeking an apology, economic parity, and equality of opportunity, the reparations advocate must consider the ways in which the sociopolitical structures can be made receptive to these remedies and begin the long and arduous task of disarming the structural and systemic perpetrators. The African-American reparations campaign, therefore, is not necessarily a linear campaign in which the apology yields the transfers that then yield promises of nonrepetition. Instead, the nonrepetition element is, perhaps explored, materialized through a reconciliation model, and then used to effectuate the apology and economic parity. ${ }^{112}$

110 This type of animus is not limited to political constituents. Neither Conyers's nor Hall's proposal was met with open or supportive responses. In fact, the most notable responses came from white political leaders whose reactions have been marked by racially divisive language and reasoning characteristic of the dominant perspective. For further discussion see generally Merida, supra note 2; Milloy, supra note 44; Clarence Page, Why So Much Opposition to President's Expression of Regret?, AUSTIN AM.-STATESMAN, April 2, 1998, at A15.

111 See discussion supra, Part I.C.

112 Of course, the campaign can proceed by seeking all of the elements at once, or transfers before apology and nonrepetition. The ordering of remedies is ultimately. 
This section explores the importance of the nonrepetition element, its dangerous absence from the current discourse, and the utility of the reconciliation-based model. The necessity of this new model is further demonstrated by a review of America's most recent domestic reparations campaign, Japanese-American reparations.

\section{A. The Essential Nonrepetition Element}

African-American reparations claims are inextricably intertwined with the material dimension of the typical reparations claim. While it suggests an attempt to effectuate massive social change, the central problem the movement seeks to remedy is the economic inequalities rooted in the complete domination of African-Americans during slavery and the subsequent Jim Crow era. ${ }^{113}$ While a massive structural change may result, and while reparationists have frequently suggested programmatic remedies, ${ }^{114}$ it is ancillary to the more specific goal of material transfers. ${ }^{115}$ To be sure, even those who may be sympathetic to the moral claims at the base of the reparations campaign believe that it is solely about monetary transfers. ${ }^{116}$

irrelevant to my thesis, which only argues for the inclusion of the nonrepetition element.

113 See TORPEY, supra note 4, at 65.

114 Reparations activists acknowledge the perception of the movement in certain corners as an organized shakedown and are proactively attempting to reframe the discussion with particular focus on the programmatic remedies requested. Programmatic remedies have been frequently suggested alternatives to cash payouts. In addition to money, reparations requests have also included world-class schools for black children, see Merida, supra note 2, scholarships, computers to black organizations, debt relief for Africa and the Caribbean, and the release of political prisoners. See Robinson, supra note 11.

115 Torpey argues that the use of the term reparations for larger social goals, such as wealth redistribution, is counterproductive, because the term suggests the notion of individual payments. TORPEY, supra note 4, at 129-30.

116 See, e.g., Kyle D. Logue, Reparations as Redistribution, 84 B.U. L. REV. 1319, 1320 (2004) ("Nevertheless, at the core of most slavery reparations proposals are calls for either cash or in-kind transfers from whites to blacks."). Indeed, some have suggested that the success of the Japanese-American movement was due in no small part to the moral claim not being sullied, explicitly or implicitly, by calls for remedies. One such commentator argues:

Focusing on the wrong, without diluting the issue with debates over remedies, helped [Japanese-American reparations] supporters attain the moral authority and momentum necessary to overcome the more daunting challenge of fashioning (and finding support for) an appropriate remedy. 
Whether it is because the term reparations is so completely associated with cash payouts and money transfers or because the African-American reparations movement has been somewhat single-minded in emphasizing the monetary aspects of the reparations claims, the need to shape the terminology is a significant component of the current wave of reparations activism. In response, there has been a push to focus the language on repair. ${ }^{117}$

This example indicates that a flaw in Conyers's bill may be its incorporation of both stages-the examination of slavery and the recommendation of remedies-into a single proposal.

Bridging the Color Line, supra note 95, at 1706. See also supra Part I.D.2. (discussing Rep. John Conyers's bill for a commission to investigate the consequences of slavery).

To be sure, there are those that are far less sympathetic that view the reparations movement as an orchestrated shakedown. Jeff Jacoby insists: "For a host of reasons, reparations are a terrible idea unjust [sic], illogical, and dangerous. . . But reparations advocates aren't interested in abstract arguments about justice and history; they are interested in extracting money from deep-pocketed corporations." Jacoby, supra note 50.

117 See, e.g., Ogletree, Litigating the Legacy of Slavery, supra note 22 ("The root of 'reparations' is 'to repair.' This litigation strategy could give us an opportunity to fully address the legacy of slavery in a spirit of repair."). Professor Roy L. Brooks, for example, has introduced an atonement model for reparations, which would seek first an apology from the perpetrator and second, reparations. The reparations would be asymmetrical - that is, it would be unlike the symmetrical Civil Rights Act, which applied to all citizens, whites and persons of color alike-and include compensatory, rehabilitative, monetary, and nonmonetary elements. Most important for the present discussion, the monetary component would be met by financial transfers to an atonement trust fund used to fund efforts and entities involved in African-American development. Roy L. Brooks, Panelist at the Thomas Jefferson School of Law Conference: Taking Reparations Seriously: A Scholarly Conference (March 17-18, 2006). Professor Charles Ogletree also disfavors individual cash payouts and advocates a similar kind of trust fund. His proposal focuses more on distributing the "billions, or perhaps trillions" to the "bottom stuck, those African-American families that have not been able to realize the American Dream fully." OGLETREe, All Deliberate SPEED, supra note 33, at 310 .

In an earlier article, Ogletree explains:

The damage has been done to a group-African-American slaves and their descendants-but it has not been done equally within the group. The reparations movement must aim at undoing the damage where that damage has been most severe and where the history of race in America has left its most telling evidence. The legacy of slavery and racial discrimination in America is seen in well-documented racial disparities in access to education, health care, housing, insurance, employment and other social goods. The reparations movement must therefore focus on the poorest of the poor-it must finance social recovery for the bottom-stuck, providing an opportunity to address comprehensively the problems of 
Irrespective of this language shift from transfers to repair, however, the reparations movement is also quintessentially backward looking. In other words, it is wholly concerned with the past violation rather than fashioning a strategy for future deterrence, the hallmark of a forward-looking scheme. While these forward-looking objectives have not been emphasized in either the historical or contemporary African-American reparations movement, they are inherent in the very term "reparations," which is often used interchangeably with distinct and overlapping terms such as "redress," "apology," "reconciliation," and "restitution." Further, whereas redress" and restitution ${ }^{119}$ tend to describe distinct campaigns, apology

those who have not substantially benefited from integration or affirmative action.

Ogletree, Litigating the Legacy of Slavery, supra note 22, at 9. Those AfricanAmerican families that have been most excluded from the American Dream would have access to the trust fund administered, perhaps, through the churches or "other reputable organizations in the community," and restricted to remedying major crises, including healthcare, housing, employment, and education. OGLETREE, ALL DELIBERATE SPEED, supra note 33, at 310-11. Ogletree recognizes that his is a paternalistic approach, but an approach, he claims, that is "entirely necessary to overcoming the problems we face." Id. at 134.

118 The term "redress" refers to the official acknowledgment of wrongdoing, and is far less concerned with monetary transfers or payouts. John Torpey explains that:

[T] he notion of reparations . . . has gained considerable momentum as a rubric under which to make claims in a variety of different contexts around the globe. However, one of the most prominent and significant campaigns concerning historical injustices-one that, indeed, set major precedents for what was to come-usually went under the term redress.

TORPEY, supra note 4 , at 46 . Torpey is referring to the campaign to address the World War II internment of Japanese-Americans. Redress activists used this term precisely to understate the monetary dimension of the claim. Id. While the reparations paid were symbolically meaningful, the redress movement was "not about the money." Id. at 47 (citation omitted).

119 Reparations and restitution are often used synonymously; however, John Torpey strongly warns against the conflation of the two. Id. Restitution is a more narrow term and is concerned with the restoration of specific items of real or personal property to their original owner. Id. at 48 . Reparations, on the other hand, has come to convey "broader and more variegated meanings." Id. Unlike restitution, "the notion of reparations suggests attempts to make up for egregiously and unjustly violated selves and for squandered life chances, rather than attempts to compel the return of goods per se." Id. However, the primacy of money transfers of some sort is crucial to this attempt at conciliation.

Hanoch Dagan offers a definition of restitution that is more relevant to the African-American experience. He defines restitution as the body of law that deals with benefit-based liability or benefit-based recovery. In the context of American slavery, restitution claims are, therefore, not about forcing the slaves to labor, but 
and reconciliation are essential and forward-looking components of a successful reparations campaign.

The apology, or statement of regret, is an articulation redolent with dynamic symbolism. "[T]o apologize is to declare voluntarily that one has no excuse, defense, justification, or explanation for an action that has insulted, failed, injured or wronged another." 120 Thus, according to Nicholas Tavuchis, "the essence of apology lies in the wrongdoer's acknowledgement of the fact of violation, the acceptance of responsibility for the wrong, and the implicit or explicit promise that similar acts will not be repeated in the future." 2121 Due to these elucidations, however, the apology is controversial when it is read in the legal context. The speaker must be aware of the concomitant liability that may result from the airing of an apology. In the legal realm, a simple, yet symbolically infused "sorry" may bind the speaker to legal-read monetary-liability. ${ }^{122}$ And while monetary transfers or payouts of reparations have accompanied the apology in certain circumstances, this fear of liability may effectively silence the potentially contrite offender. It has certainly tainted, in part, ${ }^{123}$ attempts at apology or expressions of regret by Americans vis à vis its treatment of AfricanAmericans.

All of these backward-looking efforts miss the most important element of reparations. Reconciliation must be the primary objective of efforts to come to terms with the past. ${ }^{124}$ Like the apology, it can accompany the tangible reparation, yet it is not necessarily a component part. Unlike reparations as currently conceived, reconciliation is forward looking, preoccupied with

about not paying them for the work they did. See Hanoch Dagan, Restitution and Slavery: On Incomplete Commodification, Intergenerational Justice, and Legal Transitions, 84 B.U. L. REV. 1139, 1139-40 (2004).

120 Nicholas Tavuchis, MEA CUlPa: A SOCIOlOgy OF APOlOGY AND RECONCILIATION 17 (1991), quoted in TORPEY, supra note 4, at 82.

121 Id.

122 Posner \& Vermeule, supra note 14 , at 730 . According to Posner and Vermeule, "if the background legal rules in the jurisdiction take the apology as an admission of justiciable wrongdoing," apologies may subject the speaker to monetary liability, such as cash payouts, to compensate for an injury. Id.

123 Of course, it is not clear how much this fear, versus a deep-rooted resistance to acknowledging the wrongs of slavery and its aftermath (demonstrated by responses to Hall's bill for an apology), has thwarted the formal apology.

124 See TORPEY, supra note 4 , at 82. 
the methods of deterring future bad acts. It "requires a structural and institutional dimension, a framework of rights and justice." 125 Further, it is "institutional change that will ensure a durable reconciliation and guarantees of non-repetition of the previous wrongdoing." ${ }^{26}$ African-American reparations does hint at a reconciliation component, as noted above; however, as the reparations movement is currently articulated, reconciliation is secondary and monetary transfers are "manifestly paramount."

A reparations model that includes the forward-looking objective of reconciliation would commit itself to the crucial third prong of a successful campaign: the guarantee of nonrepetition. However, that guarantee is woefully underemphasized in the current movement. Therefore, while an accompanying reconciliation model is suggested by some reparationists, for the purposes of this Article, the reconciliation model should be understood as distinct from "reparations" in the African-American context. While this distinction may be contested, it is undoubtedly true that African-American reparations is not perceived, internally or externally, as a reconciliation movement for the larger multiracial American society. In fact, it is marked as divisive in the larger majority culture, and internally it brands itself as distinct and peculiar to identifying the burdens of and exacting the benefits from addressing the African-American past.

However, this singular focus has its own perils in the American context. As demonstrated in the Japanese-American reparations campaign, the process and product of a reparations campaign may do little to ensure nonrepetition and may even reinforce the existing socioeconomic and sociopolitical hierarchy.

125 Id. at 83.

$126 \mathrm{Id}$. (emphasis added). Here, it is important to clarify that I am not suggesting that the reconciliation and nonrepetition concern itself with slavery, per se. The central wrong in the African-American context-endemic race- and class-based harm-is far-reaching, with impacts felt well into the present day.

127 Id. at 65 . 


\section{B. Japanese-American Reparations and Its Lessons}

Contemporary racism in America is covert and particularly hostile to African-Americans. ${ }^{128}$ As discussed above, for example, the legislative arena has been an unsuccessful venue for African-American reparations claims. Not all legislative attempts at repair have been similarly unsuccessful. In fact, Congress has deemed many torn communities worthy of repair. If one were to look only at past reparations struggles, other than African-American, it becomes evident that acknowledgement, apology, and redress for injuries of the recent and distant past are not inherently countercultural or worthy of summary dismissal. In fact, American society has found many injuries worthy of redress, some that were not even committed by Americans on American soil. ${ }^{129}$ For present purposes, however,

128 See, e.g., Bridging the Color Line, supra note 95, at 1705 n.88 (describing America's more covert form of racism). Lawrence Bobo's research on racial trends supports this shift from more overt forms of racism:

Bobo's research on racial trends supports the contention that for many whites, symbolic racism has replaced the overt racism prevalent during the Jim Crow era. Symbolic racism is the result of the coalescence of deeply rooted antiblack sentiments. It manifests itself in negative stereotypes, such as black intellectual inferiority or laziness, which contrast with traditional American values, such as the Protestant work ethic and individualism.

Id. (citations omitted).

129 Reparations have been awarded to several groups throughout American history. In 1851, the U.S. government began efforts to provide reparations to Native American nations. Hall, supra note 18, at 13. Since 1971, the Alaska Native Claims Settlement Act has awarded approximately \$1 billion and over 44 million acres of land to indigenous Alaskans. Id. at 16 n.86; see also Robinson, supra note 11. In 1988, the Civil Liberties Act included a formal apology and allocated $\$ 20,000$ to each Japanese-American survivor of the World War II internment camps, totaling over $\$ 1$ billion. Id. In 1993 Congress apologized to indigenous Hawaiians for the illegal 1893 overthrow of the sovereign Hawaiian nation. Hall, supra note 18 , at 16 n.86; Fletcher, supra note 48 . In December of 1999, a federal district court awarded reparations to Native Americans for the century of Indian trust fund mismanagement by the U.S. Department of the Interior and the Department of Treasury. Hall, supra note 18 , at 14. Discrete Black claimants have had success with respect to apology and restitution. In 1997, President Clinton apologized to black men left untreated for syphilis in the Tuskegee experiment. Fletcher, supra note 48. Perhaps the most telling show of support for reparations is the U.S. government's support of German reparations to Holocaust victims and our aiding of Jewish survivors in recouping their losses. In response to Germany's compensation initiatives based on state-sponsored crimes, Madeleine Albright commented, "this is the first serious initiative to acknowledge the debt owed to those whose labor was stolen or coerced during that time of outrage and shame." 
the most relevant reparations struggle is that of the JapaneseAmericans. It is relevant because it provides a cautionary tale that demonstrates the vital importance of reconciliation for the guarantee of nonrepetition.

On February 19, 1942, President Franklin Roosevelt signed Executive Order 9066 authorizing the internment of American citizens and residents of Japanese descent. ${ }^{130}$ Without charges or a trial, the U.S. government incarcerated thousands of JapaneseAmericans for the duration of the war. Forty-six years later, in response to this incarceration, the Civil Liberties Act of $1988^{131}$ sought to redress the violation of civil liberties and constitutional rights for Japanese-Americans by providing $\$ 20,000$ to survivors and an official apology to Americans of Japanese ancestry who were interned.

Some have suggested that there are many lessons that can and should be learned by the African-American reparations movement from the Japanese-American struggle. Indeed, those lessons indicate that "patience and careful issue-framing can create the interest-convergence necessary to move an AfricanAmerican reparations bill or at least a bill creating a committee to study reparations-through Congress." ${ }^{, 132}$ However, those lessons regarding approach have no true bearing on the AfricanAmerican reparations struggle. The key differences between the success of the Japanese-American reparations campaign and the centuries-old failures of African-American reparations shed light on why African-Americans are uniquely locked out of reparations gains, and, at the same time, raise a red flag for the entire enterprise if it proceeds without the nonrepetition element.

Hall, supra note 18 , at 16-17. Demonstrating support for this process, the United States considered contributing $\$ 10$ million. Id. In response to the ardent show of support for the very worthy Holocaust survivor's cause, Courtland Milloy responds with a frustration familiar to reparationists, specifically, and the great majority of African-Americans, generally. He says: "That's all well and good. But the Jewish holocaust did not occur on U.S. soil; the African American holocaust did. The U.S. government ought to help black people recoup their losses, too, especially since it was this nation that committed genocide against black people in the first place." Milloy, supra note 44.

130 Iijima, supra note 97, at 387 n.5.

131 Pub. L. No. 100-383, 102 Stat. 903 (1988).

132 Bridging the Color Line, supra note 95, at 1705-06. 
Political leaders and society at large found the reparations requests that helped to produce the Civil Liberties Act easily digestible. As Eric Yamamoto explains, the claims fit tightly within the individual rights paradigm-that is, the claimants were easily identifiable as individuals, the government agents were identifiable, and the agent's wrongful acts resulted directly in the imprisonment of innocent people. ${ }^{133}$ With this relatively seamless fit, Japanese-Americans were able to avoid the procedural barriers that dog African-American claimants.

For many Japanese-Americans, redress was not only cathartic, but it also restored a measure of dignity lost due to their internment. For this particular community, " $[\mathrm{t}] \mathrm{h}$ government's apology and bestowal of symbolic reparations fostered long overdue healing for many." ${ }^{\text {134 }}$ Yet with all of its suggestions of victory and psychological value, there was a real and very dangerous insufficiency in the awarding of reparations. In his analysis of Japanese-American reparations Chris Iijima added, "[s]ince reparations do not change the 'fundamental realities of power'... it may become a means by which 'illusions of change' are fostered, thereby perpetuating the political structures that gave rise to the original injuries." 135

Iijima's analysis is instructive for African-American reparationists. As Iijima reminds, the awarding of reparations to Japanese-Americans had a dual effect. It strengthened the international appearance of the United States with respect to its commitment to human rights. ${ }^{136}$ In addition, and most relevant

133 Yamamoto, Racial Reparations, supra note 18, at 490 . Other factors that aided the reparations claims were the following: the claimants' challenge addressed a specific executive order and ensuing military orders; the challenge was based on then-existing constitutional norms, i.e., due process and equal protection; a congressional commission and the courts identified specific facts amounting to violation of constitutional norms; the damages, though uncertain, covered a fixed time and were limited to survivors; and the payment meant finality. Id. Interestingly, however, arguments about shifting responsibility to the general public were ignored in this instance. Reparations to Japanese-Americans, totaling over $\$ 1$ billion, were paid by all U.S. taxpayers.

134 Id. at 478 .

135 Iijima, supra note 97, at 390 (citing Eric K. Yamamoto, Friend, or Foe or Something Else: Social Meanings of Redress and Reparations, 20 DENV. J. INT'L L. \& POL'Y 223, 231-32, 240-41 (1992)).

$136 \mathrm{Id}$. at 390-91. International relations were undoubtedly an important element in the granting of reparations. On the one hand, President Reagan was concurrently lobbying for improved trade relations between the United States and Japan. Bridging the Color Line, supra note 95 , at 1712 n.97. And with regard to 
to the present discussion, reparations allowed a Republican administration to "point to a 'model minority' group to defend its conservative racial policies." ${ }^{137}$ African-Americans, in the American racial hierarchy, are the antithesis of the "model minority." This "model minority" identity is a wholly unavailable marketing tool for African-Americans; indeed, African-Americans serve as the very cultural opposition that defines the term "model minority." 138

The invocation of the "model minority" identity in the Japanese-American reparations campaign, discussed in greater detail just below, undoubtedly had a negative impact on the parallel African-American reparations movement. This lessthan-subtle comparison was made worse by long-perceived links between African-Americans and inner-city maladies of crime and poverty. ${ }^{139}$ Without African-Americans having access to a higher rung in the racial ladder, reparations are outside of their reach. And to the extent that reparations campaigns in America can resignify and reentrench the American racial hierarchy, as evidenced by the 1988 campaign for Japanese-American reparations, they have the potential to be counterproductive and dangerously incomplete. At the very least, it is arguable that they can do very little to deter similar bad acts from recurring. ${ }^{140}$

\section{Japanese-Americans as the Model Minority/Superpatriot}

As the struggle for Japanese-American reparations intensified, images of Asian-American success stories were

human rights, removing one of the blemishes to its human rights record, "or at least atoning for its human rights violations, allowed the American government to denounce communism in the Soviet Union and Central Europe without fear of appearing hypocritical." Id.

137 Iijima, supra note 97 , at 391.

138 See id. at 392-93. See also TORPEY, supra note 4, at 101 (defining the "model minority" as "a group lacking the negative social and cultural traits associated with other non-white minorities in the United States, especially blacks"); Bridging the Color Line, supra note 95, at 1707 ("Portraying the Japanese-American beneficiaries as the 'model minority'-whose distinguished service in World War II, despite the internment of their loved ones at home, was critical to America's timely success in the Pacific War - was a key public relations device.").

139 See Bridging the Color Line, supra note 95, at 1707 n.96 ("Notions of the 'model minority' and institutional investment in the individual rights paradigm will do little to bolster, and could possibly hurt, the movement for African-American reparations.").

140 Discussed further in subsection 2, infra. 
prevalent. The model minority phenomenon was discussed all over the national and local press at the time of debate on and passage of the internment reparations bill. ${ }^{141}$ For that reason, the debate in Congress was absolutely colored by perceptions of Japanese-American status in 1980s America.

In addition to the advantageous model minority identity, Iijima describes two consistent themes that emerged in Congress. The first was the injustice of internment; the second, the patriotic response of the Japanese-American community throughout internment, "exemplified by their acquiescence and unqualified support of it." ${ }^{142}$ Truly, the level of patriotism demonstrated by most Japanese-Americans during World War II was extraordinary, with particular groups within the community demonstrating unusual degrees of loyalty to the government that was interning them. ${ }^{143}$ On their patriotism and

141 Iijima, supra note 97, at 393. This, according to Iijima, realizes Yamamoto's fears that Japanese-Americans' model minority status excused the government from "acting affirmatively to eradicate discrimination and subordination by emphasizing self-sufficiency." Id. at 393 n.23. Iijima quotes a number of Congressmen whose analyses of Asian-American contributions were a part of their assessment of the worthiness of reparations. He cites the following: Congressman Shumway, opposing the bill, referred to Japanese-Americans as "some of the most respectable, hard-working, loyal Americans that we have in this country"'; Congressman Levine referred to Japanese-Americans' "great contributions to our country' in 'business, architecture, science, medicine, [and] education' and declared that '[s]ome of our greatest scientists, educators and business leaders are JapaneseAmericans""; Congressman Packard said that "[o]ur Japanese friends don't need [the reparations money]"; and Congressman Brown stated that "some of Colorado's 'finest citizens . . . some of our most honest, hardworking, and productive human beings' came from the relocation camps to Colorado." Id. at 393 n.25.

142 Id. at 396.

143 For detailed discussion of the wartime contribution of the Japanese-American Citizens League (JACL), see id. at 399-410. Superpatriotism was the JACL's overall political agenda, according to Iijima. See id. at 400 . This was in the face of racial and economic persecution; and as an example of their unflinching demonstration of patriotism, the JACL aided the federal government at the expense of other Japanese Americans. Id. "Shortly after Pearl Harbor, the JACL moved toward 'formal collaboration' with the Federal Bureau of Investigation to 'inform on all individuals who appeared to be a danger."' Id. at 405 (citations omitted).

Mick Masaoka, Executive Secretary and spokesperson for the JACL, wrote the "Japanese American Creed" in 1941. It reads in part:

I am proud that I am an American citizen of Japanese ancestry, for my very background makes me appreciate more fully the wonderful advantages of this Nation. I believe in her institutions, ideals and 
acquiescence to internment, Congressman Sidney Yates (D-IL) shared a typical sentiment:

[T]his should have been enough to kill the spirit of a less responsible group of people. But the reply from the Japanese parents was to sent [sic] their children out from behind the wire fences into the American Armed Forces to fight the Nazis and the armed forces of their ancient homeland.

Iijima, who employed the term "superpatriot" to describe some of the interned, explains: "In essence, what Americans were being told by Congress to celebrate, by the giving of redress to Japanese Americans, was that patriotism-the kind of patriotism that does not resist injustice-gets rewarded."145

Eric Yamamoto likewise acknowledges that the model minority/superpatriot identity was strategically advantageous: "Framing reparations worthiness in terms of the superpatriot/model minority served several interests. Certainly, and pragmatically, it aided Japanese-American internees-they received long-overdue reparations." ${ }^{146}$ Yet in conforming to the label, definitions, and measuring sticks of the dominant culture in America, the subversive potential of a reparations campaign is necessarily vitiated. Considering the historical costs endured by African-Americans at the hands of the current societal structure, this cannot be a guiding principle. Iijima articulates convincingly

traditions; I glory in her heritage; I boast of her history; I trust in her future....

Although some individuals may discriminate against me I shall never become bitter or lose faith, for I know such persons are not representative of the majority of the American people. . . . I am firm in my belief that American sportsmanship and attitude of fair pay [sic] will judge citizenship and patriotism on the basis of action and achievement, and not on the basis of physical characteristics.

Id. at 399-400 n.42. According to Iijima, within two years of this creed the government interned Japanese Americans. Id. Notably, Congressman Matsui inserted the creed into the congressional record, $i d$, no doubt to bolster the perceived worthiness of Japanese-American claims.

144 Id. at 397 (quoting 133 CONG. REC. H7582 (daily ed. Sept. 17, 1987)).

145 Id. at 395 (quoting 134 CoNG. REC. H6308-09 (daily ed. Aug. 4, 1988)).

146 Yamamoto, Racial Reparations, supra note 18, at 501. Yamamoto seeks to meet the movement's subversive potential by seeking realization of the revolutionary potential of reparations. He asks: "Will Japanese American redress beneficiaries disavow the singular superpatriot/model minority narrative of reparations worthiness and publicly support African American justice claims?" Id. at 517 . 
the implications of the model minority/superpatriot status. He writes:

Congress expressed its solicitude for the very people whose political views accommodated and, indeed, helped to exacerbate the very injustice that Congress condemned by the redress bill. This congressional solicitude sends an unambiguous message-there are rewards for acquiescence.

... Japanese Americans should not allow ourselves to be placed in the position of accepting reparations at the same price that we were asked to pay when we were incarcerated in the first place-accommodation of governmental racial injustice. Aside from its collateral ${ }_{1}$ pernicious effects, it places us back at our original humiliation.

The impact of this favorable treatment of JapaneseAmericans on African-Americans is clear. Art Hall identifies two effects of Japanese-American reparations in the perpetuation of racism. ${ }^{148}$ First, awards to the "model minority" created selectivity in enforcement of reparations principles by whites toward certain minorities. The necessary effect, according to Hall, is continuing discrimination against AfricanAmericans. ${ }^{149}$ Second, using a more familiar argument, Hall says the "illusion of general racial harmony is created as one community of color is repaired and is nationally recognized as repaired, although the negative racial sentiments and power structure generating the original injustice remains intact." 150

Integration into and/or adoption of the dominant culture and the modes of action prescribed by it, do not threaten dominant structures of power. As such, activities that track those of the dominant culture are the most widely accepted. ${ }^{151}$ Therefore, allegiance to the dominant culture, e.g., superpatriotism, is

147 Iijima, supra note 97 , at $408-10$. On the particular position of JapaneseAmericans, John Calmore wrote: "'I do believe, however, that dominant America will attempt to situate Asians, Pacific Islanders, and Latinos squarely within its efforts to determine who will be "white" in the twenty-first century." Id. at 410.

148 Hall, supra note 18 , at 44.

149 Id.

$150 \mathrm{Id}$. Iijima argues (as does Yamamoto) that it is especially important for Japanese-Americans to not be complicit in the further subjugation of AfricanAmericans. Id. In fact, the success of their reparations movement should be judged by Japanese-Americans meeting the responsibility of work against the perpetuation of racism. Along with reparations, Iijima asserts, there is a responsibility not to excuse or perpetuate the racism that caused the internment in the first place. Iijima, supra note 97, at 393-94.

151 See Hall, supra note 18, at 34. 
lauded and equally rewarded. Patriotism, as seen in the Japanese-American context, includes a fair degree of acquiescence to the dominant culture. ${ }^{152}$ In contrast, patriotism has a particular meaning for most African-Americans, especially since patriotism and racial injustice have historically collided. Due to African-Americans' often unpleasant experience in America, their level of patriotic fervor would likely fail in comparison to those of other racial and ethnic groups. ${ }^{153}$

\section{Measuring the Success of the Japanese-American Redress Campaign: A Look at the Post-9/11 World}

The success of a reparations campaign can be measured by several indicators. However, for the purposes of the current discussion, the two most important factors are (i) the feeling of inclusion in the American social and political fabric for those who lived through the offending act, through apology and real or symbolic monetary repair; and (ii) the guarantee that the offending act will not be repeated. The latter factor is perhaps

152 Iijima writes: "Thus, the ideological baggage of the decision to redress the injustice of internment is the celebration of the "superpatriotic' response to it." Iijima, supra note 97, at 395.

153 See, e.g., Bridging the Color Line, supra note 95, at 1707 n.96 ("While black nationalist and 'Back to Africa' movements stand at the extreme, many blacks have denounced America, rather than pledged loyalty to it, because of their negative experiences in this country.").

At the same time, however, if African-Americans silence the revolutionary potential of reparations claims, African-Americans run the risk of assuaging the fear of the patriot-i.e., that the founding fathers may have launched the American society in the "dishonorable tradition of collective social deception." Cook, supra note 27 , at 990 . In other words, there is a lot for the patriot to lose in confronting American history and its legacy vis-à-vis the African-American experience, specifically, and other racial and ethnic communities, generally. Anthony Cook explains:

[T] here is the fear of public humiliation-the fear of exposing the colossal fraud of moral weakness and insecurity masquerading as Yankee ingenuity, Southern honor, and Manifest Destiny. Admitting that the slaughter, enslavement, rape, lynching, and cultural annihilation of other human beings were but stepping-stones to world prominence invites public humiliation that many are unwilling to bear.

Id. at 987 . The realization that such destructive effects are not only byproducts of all American cultural markers, like Manifest Destiny, but also the very purpose of such markers, creates an unbearable dissonance for the patriot. The alternative to such disharmony, however, is perpetuation of a status quo that continues to perpetuate similar injustices with no hint of acknowledgment. 
the single most important factor, for the guarantee of nonrepetition is the truest gift of an apology and redress.

With respect to the first factor, there is some evidence that a feeling of closure and a sense of reconciliation have remained elusive for interned Japanese-Americans. ${ }^{154}$ That feeling of elusiveness is and has been exacerbated by the sense that the violations suffered could repeat themselves, implicating the second factor. Sociologist John Torpey explains that those who lived through internment "still tend to regard the internment as a sort of unfinished business, a violation of human rights that could happen again-if not to them, then to some other group." actual or potential constitutional violations suffered by ArabAmericans have alarmed many in the Japanese-American community. In particular, the arrest and detainment without charges of many, mostly male, persons of Arab descent since late 2001 reminded many internment survivors of what happened to them in the early 1940 s. $^{156}$

Post-9/11 responses to Americans of color, specifically ArabAmericans and those mistaken for them, affirm doubts that people of color can wholly rely on "full societal acceptance and equal treatment." 157 These responses also demonstrate that "injustices that should happen 'never again' can happen again." 158 Indeed, nonrepetition, and the achievement of an

154 See TORPEY, supra note 4, at 101.

155 Id.

156 See id. at 101-02. Torpey interviewed several internees and those who fought for Japanese-Americans. One internee, Frank Kitamoto, president of the Bainbridge Island, WA, Japanese-American Community, said:

"In a way it is happening again now ... I cringe when I see the government bypassing judicial procedure by using military tribunals. . . . You wonder where it's going to end." ... Moreover, he continued, "Under the wrong climate of crisis and with a non-white population involved, it [mass arrests and internment] could happen again despite the Japanese-American redress settlement. Every Arab could be targeted and the administration won't care about the Constitution and government protocol."

Id. at 102. Similar sentiments were expressed at the 2003 Annual Day of Remembrance in Los Angeles: "One organizer of the event wrote in the publicity materials, 'As we commemorate February 19, 1942, and its aftermath, American Arabs, Muslims, and South Asians are being targeted based on the same factors." Id.

157 ld.

158 Id. at 104. 
enduring reconciliation, can only be guaranteed if there is institutional change. ${ }^{159}$

\section{III}

\section{THE POTENTIAL DANGERS OF REPARATIONS}

The discourse about reparations rings with familiar risks, including the hidden dangers of entrenched victim status, image distortion, mainstream backlash, and interminority friction. ${ }^{160}$ This Article is most concerned, however, with the inability of reparations to address the very structures that give rise to "original injuries" and the accompanying danger of "status quo enhancement." must carefully incorporate profound structural changes, rather than discrete programs and money for funding, in order to meet a larger, more advantageous, and more revolutionary goal of equity and compassion in the American society. Yet the failure of the movement to ask for such changes hints at a more systemic ailment within American society that reparationists must acknowledge.

\section{A. The Dangers in Reparations: Perpetuation of the Power Paradigm}

Racial subjugation has been a component of American capitalism since the country's earliest days. ${ }^{162}$ Indeed, numerous

159 Id. Torpey found that Japanese-Americans have realized that injustices can happen again "because structural conditions in the society have not changed, such as the potential targeting of certain ethnic groups as 'threats without evidence." Id. Indeed, Japanese-Americans were among the first to stand behind Muslims and Arabs in the days after 9/11. Id. at 103.

160 Yamamoto, Racial Reparations, supra note 18, at 482.

161 Id.

162 See generally TORPEY, supra note 4, at 25 ("Race and racial domination have been at the heart of the modern capitalist enterprise since its inception ...."). Torpey cites Marx's critique of "primitive accumulation" and its intimate relationship with racial subjugation. Marx noted that the "extermination and enslavement of the indigenous populations of the Americas, the 'looting' of the East Indies, and the massive stimulation and expansion of the slave trade in Africa had heralded the "rosy dawn of the era of capitalist production." Id. See also ManNing Marable, How CAPITALISM UNDERdEVEloped Black AMERICA 70 (1983) ("From the dawn of the slave trade until today, U.S. capitalism was both racist and deeply sexist."); Robert Westley, Many Billions Gone: Is It Time to Reconsider the Case for Black Reparations?, 40 B.C. L. REV. 429, 439 (1998) (identifying racism as a structural feature of the country's political economy). 
stories reveal the consistent conflation of capitalist development and white supremacy. ${ }^{163}$ The singular story of Tench Coxe is one example. ${ }^{164}$ Coxe, a white Philadelphian and leading political economist of the late $1700 \mathrm{~s},{ }^{165}$ was once a prominent supporter of the Pennsylvania Abolition Society. During that time he espoused a belief in a single human race, and "[f]rom this fundamental belief flowed the notion of an unracialized citizenship." 166 However, that view shifted sharply in the wake of the depression that followed the War of 1812. Soon Coxe viewed free African-Americans concentrated in the North as "an impoverished, uneducated mass for whom the rights of full citizenship were inappropriate."167 In addition to the larger economic pressure, Coxe's shift was attributed to the social influence of Philadelphia's white workingmen who were growing increasingly rabid on race issues. ${ }^{168}$

To this day, African-Americans are particularly vulnerable to the negative side effects of American capitalism. ${ }^{169}$ In short, a political-economic structure that produces profound inequities is exacerbated for those at the bottom of the societal hierarchy when there is a racial component to it. ${ }^{170}$ American capitalism

It is important to clarify here that I am not advocating a particular economic order. Marxism, to the extent that it was successfully attempted and implemented, may not have produced more favorable results than a form of capitalism that was moderated by the market's incorporation of social justice concerns.

163 See, e.g., NASH, supra note 21 , at 150-51.

164 See id. at 151.

165 Coxe was one of the most distinguished writers on American manufacturing, commerce, and political economy of his generation. Id. at 135 . In 1790 , he showed how thoroughly the Upper South was commercially dependent on links to the northern states. $I d$. at $84-85$.

166 Id. at $136-37$.

167 Id. at 150 .

168 Id. at 149.

169 Manning Marable explains:

The oppressed Black majority is generally more subject to the violence of American capitalism than whites because (1) it is concentrated in the lowest paid, blue collar, unskilled and service sectors of the labor force; (2) it comprises a substantial portion of the total U.S. reserve army of labor, the last hired and the first fired during periodic recessions; and (3) it is the historic target of brutality within a racist culture and society, occupying an inferior racial position which has remained unaffected since the demise of slavery.

MARABLE, supra note 162, at 107.

170 See id. at 106. Marable explains: 
and racial equality suffer longstanding incompatibilities, such that some of the most cross-racially honored and respected black thinkers have decried the impacts of capitalism. ${ }^{171}$ By the midtwentieth century, W.E.B. Du Bois was disillusioned with the prospects of racial equality in America. At that point, he was not only a leading voice of pan-Africanism, but he also advised that the "method laid down by Karl Marx" may be the only alternative for "the darker people of the earth." "172

The assumption that reparations must be tied to present forms of capitalism is a troubling starting point for this movement. ${ }^{173}$ It is certainly possible that a more humane American society can be achieved through capitalism. However, uncritical faith in present forms of American capitalism is practically disadvantageous. This kind of approach by African-American reparationists cannot succeed in the very value system that this reparations movement should aim to corrode. The societal actors-i.e., consumers, producers, governments, courts, and economic institutions-and the set of societal values that justified slavery and continue to justify economic suppression of

At the core of the capitalist accumulation process and institutional racism is coercion.

American capitalism is preserved by two essential and integral factors: fraud and force. Fraud is the ideological and cultural hegemony of the capitalist creed: that enterprise is free and competition exists for all in the marketplace; that success is available for all who work hard, accumulate capital, and participate as voters in the electoral process; that democratic government is dependent upon the freedom to own private property. Blacks, Latinos and white workers are barraged daily with illusions about the inherent justice and equal opportunity within the American System.

Id.

171 See TORPEY, supra note 4, at 25.

172 Id. Torpey explains that Du Bois:

[A]dmonished his readers that if an "ultimate democracy, reaching across the color line and abolishing race discrimination" could be achieved "by means other than Communism, [then] Communism need not be feared"; otherwise, there was no alternative for the darker peoples of the earth to "the method laid down by Karl Marx."

Id.

173 Reparationist Milner Ball asks: "If reparations must be tied to present forms of capitalism-at least for the time being-why should we not explore a modern equivalent of the old notion of forty acres and a mule, coupled with the provision of education and other support as was originally proposed?" Ball, supra note 48 , at 1016. 
certain members of our society ${ }^{174}$ populate the same web of values and reinforcing structures that American capitalists have today, values that reparationists work within at their own peril.

One of the fundamental, unquestioned myths integral to the peculiarly American brand of capitalism is the notion of unfettered "upward mobility." Indeed, one black economist contemplated using reparations payments from white civil society to form the basis of a black capitalism within the overall system of "white capitalism."175 Similarly, in 1997 Jesse Jackson launched the Wall Street Project with the aim of introducing more "minorities" and "minority" businesses to the world of big business. ${ }^{176}$ Yet under the veil of upward mobility, absent revolutionary spirit, there is a dangerous assimilationist strain.

This strain is dangerous for two reasons. First, assimilation asks, and often insidiously forces, an individual or community to conform to the cultural mandates of the dominant culture for that individual's or community's advancement and perhaps survival. ${ }^{177}$ While not directly advocating assimilation, adopting

174 See Verdun, supra note 19, at 637.

175 MARABLE, supra note 162, at 164-65 (noting black economist Flournoy A. Coles Jr.'s description of a corporate property and federal tax revenue that could form the basis for reparations payments).

176 See Hall, supra note 18 , at 9 n.41. See also Carter, supra note 12, at 1022 (arguing, in response to Professor Cook's reparations argument, that "most of those responsible for implementing a reparations plan may not desire a beloved community; indeed, a less than beloved community serves some economic purposes to a higher degree because it supports the division of society into classes."). In fact, as Cook concedes, the perpetuation of the "less-than-beloved" community is a source of incredible wealth and economic power. Id. at 1028.

177 See Cook, supra note 27, at 964 n.11. While diametrically opposed to Jacksonlike goals, Dinesh D'Souza expresses an extreme of assimilationist sentiment. $\mathrm{He}$ argues: "[F]or generations, blacks have attempted to straighten their hair, lighten their skin, and pass for white. But what blacks need to do is to "act white," which is to say, to abandon idiotic Back-to-Africa schemes and embrace mainstream cultural norms, so that they can effectively compete with other groups."' Id.

Japanese-American assimilation was an unparalleled community asset in the quest for reparations. John Tateishi, now a prominent leader within the JapaneseAmerican community and a major architect of the Japanese-American redress campaign of the $1970 \mathrm{~s}$ and $1980 \mathrm{~s}$, affirmed that "the Japanese-Americans' willingness to abandon their traditional ways and to assimilate into American society played a major role in this development." TORPEY, supra note 4 , at 85 . In his view, only through assimilation can ethnic groups in American society overcome the obstacles they face in gaining political influence. Id. He emphasized that, in order to become American, Japanese-Americans had to give up their culture of origin: "'Assimilation was one of the key factors for us. It was one of the prices we were willing to pay to become American." Id. 
familiar methods of upward mobility for Jackson and reparationists leads the movement into an adoption of mainstream cultural norms. While African-Americans might be more able to "compete," they will also be complicit. ${ }^{178}$ And, equally relevant, because racism in our society is so pernicious, that complicity will not yield a fully favorable result. ${ }^{179}$ Certainly, wealthy African-Americans are not free from the disadvantages of antiblack sentiments.

Second, the current reparations paradigm may also encourage the proliferation of the "Black Capitalist." Manning Marable expresses a concern regarding the co-opting potential of American capitalism by identifying the-capital "B", capital "C"-Black Capitalist. He explains that the "crisis of modern capitalism may push the advocates of Black Capitalism squarely into the camp of the most racist and conservative forces of white America." 180 Indeed, Jackson's Wall Street Project incorporates many key concepts of Black Capitalism, including the accumulation of capital by individual black entrepreneurs; strategies designed to maintain black control over the black consumer market in the United States; and collective programs to improve the economic condition of all blacks within the overall framework of U.S. capitalism. ${ }^{181}$ The danger of such a project is a flawed theory of economic development at its base-

178 Cook provides an excellent example of this potential and actual complicity. He writes of the recent history:

$[\mathrm{M}]$ any liberals often failed to understand or acknowledge how . . the Cold War's domination of foreign people abroad [was] connected to racial and class subordination at home. King understood that black and poor people of every race were fighting against other people of color in Vietnam so that industrial capitalists could secure markets for the sale of military and nonmilitary goods, the profits of which would further consolidate the power of the military/industrial elite.

Cook, supra note 27, at 997. Today, participation in American capitalism results in one engaging in a system that is unsustainable from an environmental vantage point.

179 As Cook reminds: "We must see and admit that racism has not only limited opportunities available to blacks, but also has limited what blacks can do with those opportunities once presented." Id. at 994.

180 MARABLE, supra note 162 , at 167 . Worse still is the power of the nonwhite capitalist to sanitize the current system. Marable explains: "The goal of the Black entrepreneur is to make profits, period. How he/she accomplishes this task is secondary to the goal. The nonwhite businessperson is the personification of the legitimizing and rational character of capitalism." Id. at 138.

181 Id. at 139 . 
flawed because it incorporates a dangerous myth that American capitalism is race neutral such that capital accumulation alone can be a panacea for African-Americans. ${ }^{182}$ However, the racial hierarchy is so inextricably interwoven into the capitalist economic hierarchy that reliance solely on capital is ultimately self-defeating.

Ultimately, however, the reparations movement's reliance on traditional hallmarks of American capitalism suggests a lack of innovation and optimism in conceiving of an alternative future. ${ }^{183}$

\section{B. Postutopia and the Future}

The contemporary reparations movement's focus on capital may be an indication of a growing pessimism among those on the Left, generally, and those struggling for civil rights, specifically. This push for remedying the past is symptomatic of a severely diminished faith in shaping a progressive future. In fact, looking to the past is a form of activism in "a period of progressive paralysis and disarray." 184 Consequently, "coming to terms with the past" has displaced more utopian possibilities for the future. ${ }^{185}$ For African-Americans, this is particularly true at a time when the political Right is experiencing unparalleled influence. The ascendancy of the Right in the arena of race politics has crippled the momentum toward racial equality that defined the sixties and seventies, and is evidenced by, for example, the current challenges to affirmative action from the

\footnotetext{
182 See id.

183 This lack of innovation reflects, perhaps, the diminished expectations from which the racial and economic subaltern now suffer as a result of the rise of the right at the turn of the twenty-first century. It is also important to note here that the struggle for " 40 acres and a mule" has not always represented a lack of innovation and optimism. In the earlier days of American capitalism awarding of " 40 acres and a mule" might have provided the amount of capital needed to sufficiently empower the newly emancipated. With the full inclusion of the formerly enslaved, a different kind of American capitalism might have evolved with the input and participation of individuals other than monied white men. Today, however, the equivalent of " 40 acres and a mule" could not produce this alternative, and arguably more egalitarian, social structure. A more decisive change is now in order.

184 TORPEY, supra note 4, at 4 . John Torpey makes a convincing argument regarding the emergence of past-oriented movements, led by reparations movements, worldwide. See id. at 4-5.

185 Id. at 8-9.
} 
Right. ${ }^{186}$ With the growing resistance to the advancement of the civil rights era, the Left and reparations activists are literally looking backward.

This looking backward is indicative of the greater retreat of progressive thinking. ${ }^{187}$ The shifting of focus toward a backward-looking reparations paradigm is both the result and indication of a diminished vision of an alternative future. ${ }^{188}$ Now, "the quest of active citizens and mobilized constituencies" for social change, which marked the civil rights movement for example, is increasingly displaced by legalities alone. ${ }^{189}$ This

\footnotetext{
186 See id. at 26.

187 Torpey states: "Almost by definition, earlier progressive politics saw the past
} as a lower, more backward period that was to be left behind as retrograde-or that, as a result of its dialectical contradictions, was the womb of a brighter future." Id. at 158. Torpey identifies a "major shift in much progressive thinking from a focus on the future as the proving ground of social change to a preoccupation with the past as the arena in which to seek improvements in the human condition." Id. at 41. This is not at all how progressive thinking used to conceive of social change; in fact, looking to the past ran counter to organized change.

For Marx, the past was a brake on progress and nothing more than a foundation for a utopian tomorrow. Id. at 10-11. People were in a condition of exploitation and lived under unjust social arrangements. Id. at 11 . In effect, what was segregating people from achievement of their own "essential being" was unjust arrangements in the present, not "any uncompleted project of fixing the past." Id. Therefore, to achieve change, people had to overthrow these arrangements.

188 Torpey insists that this is more than a mere coincidence. He writes:

[T] he rising concern with the past overlaps so directly with the decline of more explicitly future-oriented politics that it is hard to avoid the conclusion that this is more than mere coincidence. The intensive and often censorious attention to the past is a response to the 'collapse of the future'-the decline of the bold, progressive political visions that had been embodied in the socialist movement and, in a larger sense, in the project of the nation-state understood as a community of equal citizens.

Id. at 22 .

Hannah Arendt was also forward looking in her philosophical approach. Arendt sought "'not to restore an imagined moral order that has been violated but to initiate new relations between members of a polity." Id. at 14. For Arendt, there is no community to resuscitate-a position that is particularly relevant in the American context. Arendt advocates only the creation of community, in "an everreceding, asymptotic approach to something like the vision of a "beloved community' that animated the early civil rights movement." Id. at 14-15.

189 Id. at 15 . Torpey maintains:

In the absence of a plausible overarching vision of a more humane future society, the significance of the past and of people's recollections of it become magnified; righting past wrongs tends to supplant the search for a vision of a better tomorrow. The reckoning with abominable pasts becomes, in fact, the idiom in which the future is sought. We might call this 
increase tracks an overall pessimism regarding the future that the Left exhibits today. ${ }^{190}$

In the midst of such diminished expectations about the future, the past becomes increasingly attractive. Progressive thinkers and activists are now looking at the past as the space that they can fix, and the current paradigm of reparations politics is the perfect tool. ${ }^{191}$ With the definitive end of the early, intercultural, and interracial civil rights movement, African-American reparationists are gazing in a similar direction. To be sure, the

the involution of the progressive impulse that has animated much of modern history - the deflection of what was once regarded as the forward march of progress and its turning inward upon itself in a climate of conservative dominance.

Id. at 37.

190 François Furet comes to a stark conclusion regarding the elusiveness of an alternative future. He writes: "The idea of another society has become almost impossible to conceive of, and no one in the world today is offering any advice on the subject or even trying to formulate a new concept. Here we are, condemned to live in the world as it is." FRANCOIS FURET, THE PASSING OF AN ILLUSION: THE IDEA OF COMMUNISM IN THE TWENTIETH CENTURY 502 (Deborah Furet trans., Univ. of Chicago Press 1999) (1995). This depth of melancholy is evident today. For example, despite adopting the motto "[a]nother world is possible," participants at the 2002 Pôrto Alegre alternative summit on globalization, held to coincide with the annual conclave of the world's leading capitalists, the World Economic Forum in Davos, failed to sketch an alternative to the intricately conceived path of globalization. TORPEY, supra note 4 , at 36 . When asked about the failure, Brazilian novelist and attendee Moacyr Scliar stated: "The political horrors of the twentieth century taught us that it's better we don't leave here with a magic formula." Id. at 36-37.

191 Torpey argues that this posture "was consistent with the fact that 1989 was a kind of Rubicon for the left, which sustained a historic defeat as advocates of free markets and liberal individualism gained the ascendancy over those who sought to rein them in. As a consequence, the politics of utopia lay in shambles." TORPEY, supra note 4 , at 160 . Torpey explains and critiques the retreat to reparations as follows:

[R]eparations politics begins from the assumption that the road to the future runs through the disasters of the past. This is a circuitous route to a brighter day, but it is one of the few that seems available in a post-utopian, privatizing, business-mad era. The problem is that, unlike a politics that invokes a vision of progress and redemption for all regardless of race, color, or creed, reparations politics is open to impugning because it inevitably provokes the response that it serves only partial, narrow interests.

Id. at 5-6. 
post-civil rights era activists are scrambling for a well-articulated, common vision. ${ }^{192}$

As evidence, the tepid support among African-Americans for reparations, including an apology, or payment of a different kind, suggests that there has not been an inspiring and fervent campaign amongst the very group reparations is meant to benefit directly. For example, polls have consistently found that three to five out of ten African-Americans support neither an apology nor financial transfers of any sort. ${ }^{193}$ The lack of a future-oriented goal is worsened by the fact, or perhaps caused by the fact, that there is no popular movement at base. ${ }^{194}$ A fervent groundswell is absolutely in $\operatorname{order}^{195}$ if reparations are to gain any traction. However, for the reparations movement to gain traction, it must incorporate the future-oriented mandates of reconciliation and nonrepetition.

Reparationists maintain that the current movement's focus on the past is still crucial to the social change that needs to occur in our society. In fact, some reparationists, such as Alfred Brophy,

192 Richard Epstein, a far more cynical commentator, proffers his own explanation, stating:

[S]ince 1965 the Civil Rights Movement has suffered from "the March of

Dimes" problem. Once you have rid the nation of polio, what do you do for an encore? The civil rights equivalent is that the fall of segregation ended the struggle against obvious human rights violations. In its place came complex debates over antidiscrimination laws, affirmative action programs and the like.

Epstein, supra note 81, at 1191-92.

193 See Fears, supra note 49 (citing a 2002 CNN/USA Today/Gallup poll showing that half of African-American respondents said the government should make cash reparations payments, and 68 percent said that the government should apologize to African-Americans for underwriting slavery); see also Harris, supra note 10 , at 410 n.9 (noting that while 90 percent of white Americans oppose cash reparations, even many African-Americans "are plainly distressed by talk of reparations," with 37 percent of African-Americans opposed to cash reparations).

194 The absence of that base forces one African-American commentator, Adolph Reed, to critique: "What strikes me as most incomprehensible about the reparations movement is its complete disregard for the simplest, most mundanely pragmatic question about any political mobilization: How can we imagine building a political force that would enable us to prevail on this issue?"' TORPEY, supra note 4 , at 121 .

195 The reparations movement's current tack, with great emphasis on legal remedies, is, so to speak, going it alone. John Torpey opines that "it is not clear that legal casuistry is well-suited for bringing about substantive social change; for such change to occur, legal maneuvering may provide some help, but popular mobilization is an essential element as well." $I d$. at 108. 
are suspicious of calls only to look toward the future. Brophy rightly argues:

It merits mentioning that a dialogue concerned with prohibiting discussion of the past is, at botton, a call to passively accept the current distribution of power and wealth. And while it may be correct that a focus on the past is distracting to those who should be focused on the future, calls to not talk about the past still deserve scrutiny because they prevent an inquiry into the justice of the current asymmetrical distribution of wealth.

The absence of a future-oriented approach is conspicuously dangerous, however, particularly because the future is the only space that can truly be fixed. ${ }^{197}$ Further, the sharp focus on the past ignores the exigencies of the present, which would dictate a movement that is equally concerned with the African-American condition as it is with the racial and/or economic subjugation suffered by many in American capitalism. ${ }^{198}$ Indeed, the reparations movement should shift to a cross-racial, coalitionbuilding that is forward looking and focused on structural reparations. Structural reparations would incorporate into the current reparations campaign the means and methods of the reconciliation model and the results that ensure the guarantees of nonrepetition.

Solidarity-building for this broader purpose is as old as all struggles for racial equality undertaken by African-Americans. Dr. King universalized his initial, more singular demand of civil rights to the pursuit of economic and human rights. King's shift

\footnotetext{
196 Brophy, supra note 56, at 210.

197 Torpey warns of this uneven weight reparationists place on the past. $\mathrm{He}$ writes:

Given its preoccupation with past injustices, reparations politics may tilt our attention excessively toward a history about which, in fact, little can be done.... Without neglecting the ways in which the past ramify into and in a certain sense even constitute the injustices of the present, we must always bear in mind that it is only the future that we can really do anything about.

TORPEY, supra note 4 , at 166.

198 Again, Adolph Reed critiques the narrow scope of the movement, remarking that at a time when "'common circumstances of economic and social insecurity have strengthened the potential for building broad solidarity across race, gender, and other identities, . . . demand for racially defined reparations . . . cuts precisely against building such solidarity."' $I d$. at 122 (noting also that Reed's argument points toward transforming the idea of race-based reparations to a class-based demand).
} 
in focus to the Poor People's Campaign, prior to his untimely death, is a testament to that broader rights-seeking movement. ${ }^{199}$ And, in coming to this resolution, King was following in the path of earlier black activist clergy, such as Henry Highland Garnet and Nat Turner. ${ }^{200}$ These activists all called for radical and fundamental change, and raised issues that could not be resolved in the system as it stood, and continues to stand.

\section{C. "Dominant Culture Kills Revolutionaries": ${ }^{201}$ Focused Requests for Structural Reparations}

It is essential that the remedies that the contemporary African-American reparations movement seeks be both crafted in isolation of the dominant culture and mindful of creating cross-racial and cross-cultural coalitions for combating universal ills, such as poverty. ${ }^{202}$ Though reparationists may question how a generalized remedy can be responsive to the specific struggle for African-American reparations, those concerns are necessarily mooted by the realization that this type of large-scale request is the only way to ensure nonrepetition.

Accordingly, in the structuring of remedies, AfricanAmericans must keep Eric Yamamoto's insights at the forefront. He identifies a normative and descriptive model of reparations. The normative model says that reparations should be aimed at restructuring institutions and relationships that gave rise to (and sustain) the underlying justice grievance. ${ }^{203}$ The descriptive model warns:

${ }^{199}$ In fact, as the struggle wore on, "King concluded finally that the defeat of racial segregation in itself was insufficient for creating a just and decent society for all Americans." MARABLE, supra note 162, at 210.

200 Id.

201 Cook, supra note 27, at 960. Mari Matsuda gives voice to this sentiment by writing that "reparations buys off protest." Matsuda, supra note 59, at 397 . She poignantly advises that, as currently articulated, an award of African-American reparations will "portray the government as benign and contrite. Reparations buys off protest, assuages white guilt, and throws responsibility for continued racism upon the victims. 'We paid you, why are you still having problems?" Id. Cook's discussion of King's Beloved Community provides a valuable blueprint for the psycho-spiritual goals and methods of the Community and its reparations movement.

202 Mari Matsuda warns that in order to avoid the type of "corruption" possible in reparations payments, remedies must be defined by the victims. See Matsuda, supra note 59, at 397.

203 Yamamoto, Racial Reparations, supra note 18, at 518. 
[R]estructuring those institutions and changing societal attitudes will not flow naturally and inevitably from reparations itself. Dominant interests, whether governmental or private, will cast reparations in ways that tend to perpetuate existing power structures and relationships. Indeed, traditionally framed, American interests in racial reparations, including international credibility and domestic peace, tend to reinforce the social status quo.

For once, American society must be steered toward the normative model. The descriptive model, describing the familiar two-pronged reparations approach, militates in favor of a strong focus on the third element. Yet, the important first step is perhaps the most difficult. An apology should not be undervalued in this debate. In fact, examples above of how hostile white Americans and white leaders are to the very suggestion of an apology indicate its weight. ${ }^{205}$ An apology requires a level humility that will be an essential early shift for America toward a more inclusive social and political economy. From that apology, symbolic reparations may be paid. However, in contemplating the means and methods of repair, reparationists still must conceive of a restructured American society.

Thinking about large-scale change will spawn social innovations large and small. Structural reparations will necessarily range from, for example, the concrete goals of universal healthcare and the free and equal access to highquality public education to the broader goal of "triple bottom line" accounting for both public and private decision making. Under the triple bottom line model, for example, social justice and environmental health and equity join financial outcomes as integral indicators of success. ${ }^{206}$ Rethinking the goal of the

204 Id.

205 Martha Minow writes: "The apology reminds the wrongdoer of community norms because the apology admits to violating them. By retelling the wrong and seeking acceptance, the apologizer assumes a position of vulnerability before not only the victims but also the larger community of literal or figurative witnesses." MARTHA MINOW, BETWEEN VENGEANCE AND FORGIVENESS 114 (1998).

206 For greater discussion on triple bottom line accounting and reporting, see, e.g., Ann L. MacNaughton \& Jay G. Martin, Practical Impacts of Sustainable Development on Energy Law, NAT. RESOURCES \& ENV'T, Fall 2004, at 33; Wayne Norman \& Chris MacDonald, Getting to the Bottom of "Triple Bottom Line", 14 Bus. ETHICS Q. 243, 244-45 (2004); William L. Thomas, Rio's Unfinished Business: American Enterprise and the Journey Toward Environmentally Sustainable Globalization, 32 ENVTL. L. REP. 10873 (2002); Frank Vanclay, The Triple Bottom 
reparations struggle will encourage similar new and appropriate solutions. A renewed energy and optimism from the left will necessarily follow, ${ }^{207}$ making these kinds of reparations requests feasible despite what decades of opposition, or at best, disregard, might suggest.

The recent disclosures of companies that were complicit with slavery and benefited greatly from its perpetuation also provide myriad extralegal possibilities. Most reparationists are using this information as a solid basis for monetary claims against private institutions and eventually against the U.S. government. However, this information might be most valuable for its insistence upon moral accountability. With the acknowledgement of the way in which profit can egregiously impede humanitarian action, companies must be encouraged to learn a lesson in which calculating the bottom line necessarily includes the impact on peoples and cultures. This will have to include full-scale and well-orchestrated boycotts of the egregious offenders. Companies should be forced to incorporate that lesson in today's market approach, especially as it continues to focus on least developed (poor and of-color) countries.

Of course, memory is also an integral part of any true reparations. In fact, as Milan Kundera reminds, " $[\mathrm{t}]$ he struggle . . against power is the struggle of memory against forgetting." "208 American society is notorious for its remarkably short memory. Making visible the links between our slave holding past and our racism-riddled present will be a difficult but vital step. The recognition of those links must be followed by their permanent imprint on our collective history. To that end, a commitment to communicative histor ${ }^{209}$ - to an accurate and

Line and Impact Assessment: How do TBL, EIA, SEA and EMS Relate to Each Other?, 6 J. ENVTL. AsSESSMENT POL'Y \& MGMT. 265, 267 (2004); Martin Whittaker, Emerging "Triple Bottom Line" Model for Industry Weighs Environmental, Economic, and Social Considerations, OIL \& GAS J. Dec. 20, 1999, at 23 .

207 This would be particularly true today, if in the spirit of the civil rights movement, African-Americans once again take the mantle of social justice and channel the great energy generated by those in opposition to the current course of the nation under the leadership of the far Right.

208 MiLAN KUNDERA, THE BOOK OF LAUGHTER AND ForgetTing 3 (Michael Henry Heim, trans., Knopf 1980) (1978).

209 To be sure, the term "reparations" has come to describe much broader remedies. Alternative remedies include, for example, communicative history. "Communicative history" describes the kind of history writing that results from a 
comprehensive rewriting of our history books-can be a central goal for structural reparationists. Our use of monuments and visual markers must also be a part of the structural reparations project. ${ }^{210}$ Not only do "symbolic" remedies have intellectual capital, they also have moral value. Dollar-based reparations neither suffice in a human calculus nor leave an indelible imprint on the American consciousness.

\section{CONCLUSION}

For African-Americans, academics, and everyday reparationists, the reparations struggle undoubtedly has been valuable because of the lively discourse it has spawned. Because of this discourse the current African-American reparations movement is a helpful step towards the broader movement I advocate. Although some characterize the discourse to be occurring only in the margins, ${ }^{211}$ a revitalized movement is important and can be both relevant and successful in American culture if it prioritizes the vital prong of nonrepetition.

If the reparations discourse is truly concerned with meaningful and lasting change, it must vigorously define its space in the fight for social justice. And if it is truly concerned with equalizing the playing field for African-Americans today, as it purports to be, it must commit itself to the goal of nonrepetition. In achieving that goal, it is imperative that

consensus among varied parties to a particular past, including, most significantly, the party that has been most profoundly and negatively impacted by the history in question. See TORPEY, supra note 4, at 49-50. In order to develop the desired "communicative history," the parties must, among other things, scrutinize and revise school textbooks, erect commemorative plaques, monuments and memorials, and introduce national days of remembrance. The ultimate goal of this type of history writing, and the best that history can do, is "to serve the future [and] . . to make certain statements impossible by documenting beyond the shadow of a doubt that this actually happened." Id. at 76 . This and other forms of "political symbolism" can accompany the ultimate method of repair.

210 Martha Minow writes: "Symbolic reparations such as the creation of peace parks for children or schools named for individuals murdered during the atrocity challenge [the] equation of persons and things and potentially speak to the individuality and dignity of those who were victimized." MINOW, supra note 205, at 132.

211 See Hall, supra note 18, at 22. As Hall warns: "Without a judicial basis for resolution and without any congressional progress towards action, the little debate that does exist has largely centered in coffee shops, barber shops, Black churches, and academic arenas." Id. 
African-American reparationists consider cross-racial, crossethnic coalitions and advocate on behalf of more generalized remedies for economic inequality. Indeed, that is the only way the movement can begin to ensure that the central wrong will not be repeated and truly achieve a successful reparations campaign. What is of primary and immediate importance is that the true purpose of the movement not get lost in the morass of numbers. It is vital that the African-American reparations movement incorporate a progressive opposition to American economic, cultural, and gender hierarchies that are perpetuated by the American brand of capitalism. ${ }^{212}$

Though the task may seem daunting, the African-American community is noted for its determined ability to strive and survive through creativity. ${ }^{213}$ A reevaluation of the contemporary reparations movement that places structural change at its core will recognize the African-American identity and experience as an important part of the suppressed American story, subvert the current reality of the dominant culture, and offer the potential for creative strategies to focus on a positive future and build cross-ethnic coalitions in getting there. This is, of course, not a simple task; however, the remedies should at least attempt to be as sweeping and seismic as the wrong of enslavement, subjugation, and unfettered profit continue to be.

212 Manning Marable inspiringly advises:

The burden of our history is two-fold. We must advance "reformist" programs within communities which reinforce Black owned socioeconomic and cultural institutions, advocating the maintenance of needed social service programs that affect the Black working class and the poor. But we must insist uncompromisingly that the social crises confronting Black people reflect a more fundamental contradiction created in part by the crisis of capital accumulation. Self-determination for the Black majority cannot be forged unless our politics, in theory and in practice, also opposes sexual exploitation, imperialism, and monopoly capitalism. The revolt for reforms within the capitalist state today transcends itself dialectically to become a revolution against the racist/capitalist system tomorrow.

MARABLE, supra note 162, at 194.

213 See Matsuda, supra note 59, at 335 (quoting Erlene Stetson "“[c]reativity has often been a survival tactic.' Studying the centuries-old tradition of American black women's poetry reveals ... three major elements: 'a compelling quest for identity, a subversive perception of reality, and subterfuge and ambivalence as creative strategies."'). 